\title{
Management of Furrow Irrigation Technology and Its Risk Assessments: A review
}

\author{
${ }^{1}$ Abou Seeda M.A., ${ }^{1}$ Yassen A.A., ${ }^{2}$ Abou El-Nour E.A.A. and ${ }^{3}$ Hammad S.A., \\ ${ }^{1}$ Plant Nutrition Dept., National Research Centre, 33 El Buhouth St., 12622 Dokki, Giza, Egypt. \\ ${ }^{2}$ Fertilization Tech. Dept., National Research Centre, 33 El Buhouth St., 12622 Dokki, Giza, Egypt. \\ ${ }^{3}$ Soil and Water Dept. Fac.Agric. Mansoura University, Egypt.
} Received: 05 August 2020/ Accepted 10 Oct. 2020 / Publication date: 15 Oct. 2020

\begin{abstract}
The effective way to resolve the shortage of agricultural irrigation water resources is the research and application of new water-saving technology of surface irrigation in Egypt. Surface irrigation is the most common executed irrigation due to its low cost, no special technical experience regarding operation, maintenance and specific equipment are required Furrow irrigation is most widely used among the surface irrigation methods. Applying by small channels or furrows, which follow a uniform longitudinal slope. Efficiency of furrow has low application due to its high water loss through surface runoff, evaporation from water in the furrow itself, evaporation from the soil surface and percolation below root zone. Alternate furrow irrigation is a system of irrigating only one side of the plant, i.e., half of the root system, is irrigated at first irrigation event, while the other side receiving water next time. Two advanced water-saving irrigation technologies for improving ground irrigation technology and the precision surface irrigation technology for improving water use efficiency. Application of the these technologies, may improve the irrigation management and the quality of surface irrigation, obtain the effect of save water and increase production, promote the development of modern agriculture in Egypt, Furrow bed is the most efficient traditional surface irrigation method. The main reasons being attributed to lack of knowledge of furrow bed design, installation and management. Egypt is a major irrigated agricultural country with more than $90 \%$ of crop production coming from irrigated areas. Either irrigation water available at farm gates from surface or groundwater resources are more precious, thus demands a more efficient use. However, unfortunately more than $50 \%$ of this water is lost due to poor irrigation management practices on farms. Flooding, flat basin and irregular and unleveled border irrigation methods are the norms on majority of farms, which is inherently inefficient. Irrigation technologies such as drip, sub drip are costly and require knowledge that is more technical, thus, negligibly adopted and are generally considered as late time solutions. Although furrow bed irrigation, a relatively more efficient irrigation method, has been adopted, especially for row crops but decision support guidelines for their appropriate installation and management is very limited, thus, potential benefits of furrow beds are yet to be achieved consequently; water productivity of major crops is below global. We consider sustainability to be achieved when irrigation and drainage are conducted on-farm, and within irrigation districts, that does not degrade the quality of land, water, and other natural resources. Describing as maintaining the productive resources required for irrigation, therefore, generations may have the same opportunity to use those resources as we do. Adoption of this strategy may enhanced by policies that require farmers, and irrigation districts, to consider the off-farm impacts of irrigation and drainage. Review illustrating some key guidelines for the appropriate installation and management of furrow bed irrigation method on farms, that may increase decision support and furthermore, increasing water productivity.
\end{abstract}

Keywords: Furrow irrigation technology, management, risk assessments

\section{Introduction}

Egypt presents a unique context for water accounting, rainfall is practically low; irrigation is served by controlled releases from Aswan, and inland return flows all return to the Nile system. This means that increasing irrigation efficiency are extremely unlikely to save real water, except than for the potential reduction of some non-beneficial water consumption (i.e. free water surface and wet soil evaporation) (Alexandratos, and Bruinsma 2012; Jägermeyr et al., 2015). At the coast, the situation is more complex: excess freshwater deliveries to irrigated areas serve to control saline intrusion. Egypt is

Corresponding Author: Abou Seeda M.A., Plant Nutrition Dept., National Research Centre, 33 El Buhouth St., 12622 Dokki, Giza, Egypt.E-mail:mabouseeda@gmail.com 
a unique irrigation environment. More than 95 percent of the country's water resources come from the Nile as inflow from upstream catchments; rainfall is negligible. Hydro logically, this makes analysis of water utilization relatively simple: all return flows from excess irrigation applications go either to groundwater (which is in equilibrium in the surface irrigated areas, and over-drafted in newly developed areas in the western delta), or back via the drains to the surface system except at the northern interface with the Mediterranean. In that area, saline intrusion is a problem, so that releases of fresh water to the sea are required to maintain equilibrium and to flush out pollutants. Egypt is thus a classic example of recoverable flows, and "on farm efficiency" is of modest relevance to water saving (Elsheikh et al., 2014). Despite this, many millions of dollars have been spent on on-farm irrigation development (e.g. Ministry of Agriculture informal communications) designed to increase on farm irrigation efficiency and, as late as 2015, the "On farm Irrigation Development Project" reports6 that large quantities of water can be "saved" through increased "efficiency" from 50 percent to 80 percent in the old lands, allowing expansion of the irrigated area elsewhere (FAO, 2012, 2017, 2019)

\subsection{Measurement of water use efficiency}

Distribution boxes are useful for effective and equal distribution of water among the ditches, but they require proper maintenance. Boxes were hit by overtopping, so erosion occurred around the structure. The soil erosion led to the falling of the grounding and to the complete deterioration of the structure. Furthermore, missing valves were not replaced, but replicated with grasses, so it did not provide impermeable closing. Distribution boxes are not prepared for water off take; rather the gates are designed for water withdrawal, while boxes are deployed for distributing water. Therefore, each outlet has its own valve ( 4 in totals) to protect the canal and the lands from unintended water flow. Each type of distribution box has its own design capacity, which should not be exceeded. Distribution box and the border of the farm covered by weed Water infiltration through furrows Photo (1).
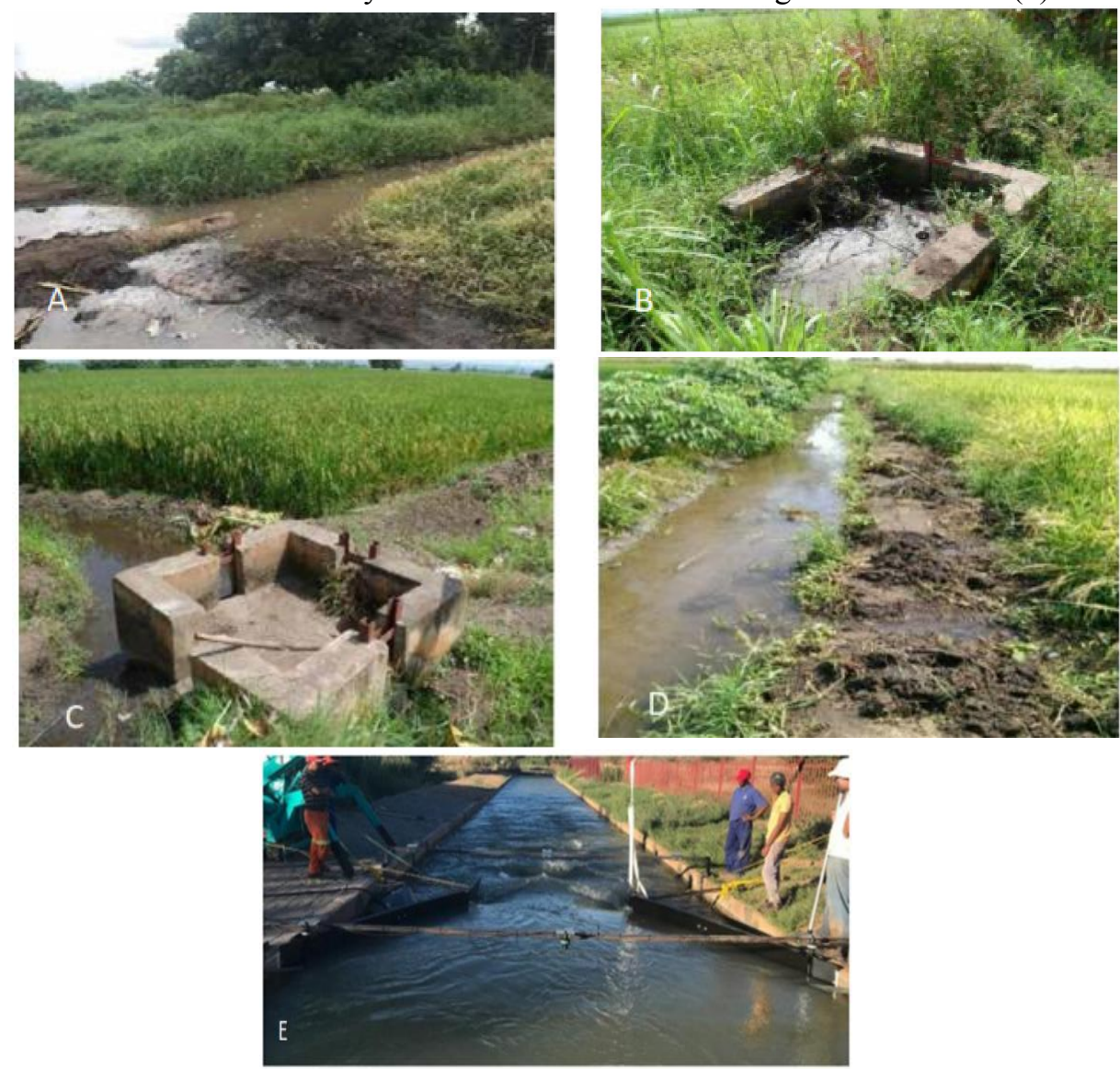

Photo 1: A : Large-size drains, B : Destroyed distribution box, widened and unshaped quaternary canals $\mathbf{C}$ : Destroyed distribution box, Widened and unshaped quaternary canals D : Sedimentation deposit in quaternary E: Hydrokinetic turbines and enhance water use efficiency after FAO (2019) 


\subsection{Water use efficiency measure: Sediment removal}

There are many sources for siltation, sediment or debris along canals. The first major source is located where water is withdrawn. If the irrigation scheme is not equipped with trapping or filtering structures at the entry stretches, water transports silt and sediment, which can damage the intake structure, deposit on the canal banks and on bottoms, thus, decreasing the system performance. The canal can be also subject to debris flow deposition along the way. The siltation, sedimentation and debris deposits decrease the system performance and damage the structures. Cleaning, de-silting, removal of deposits is the first step of routine maintenance. Regular cleaning by excavation helps maintaining canal performance and prevents deterioration of the system. Cleaning does not require expensive equipment and can be done manually in small canals (e.g. by digging hoe). However, cleaning should not modify the original system design. An earthen canal should, thus, be cleaned and sand deposit should be removed while respecting the original dimensions of the canal. The sediment load of water highly depends on water source. If water comes from earthen ponds or dams, for example, it can carry larger load of sediment than a canal sourcing water from a high-velocity river. Even if the majority of irrigation systems are not equipped with sediment filters at the intake gate, farmers can deploy techniques to deposit the sediment in the canal before applying water on their fields. Small sediment basins on the canal bed help depositing the undesired sediment. If the tertiary canals are unlined, digging a small whole Photo (2).
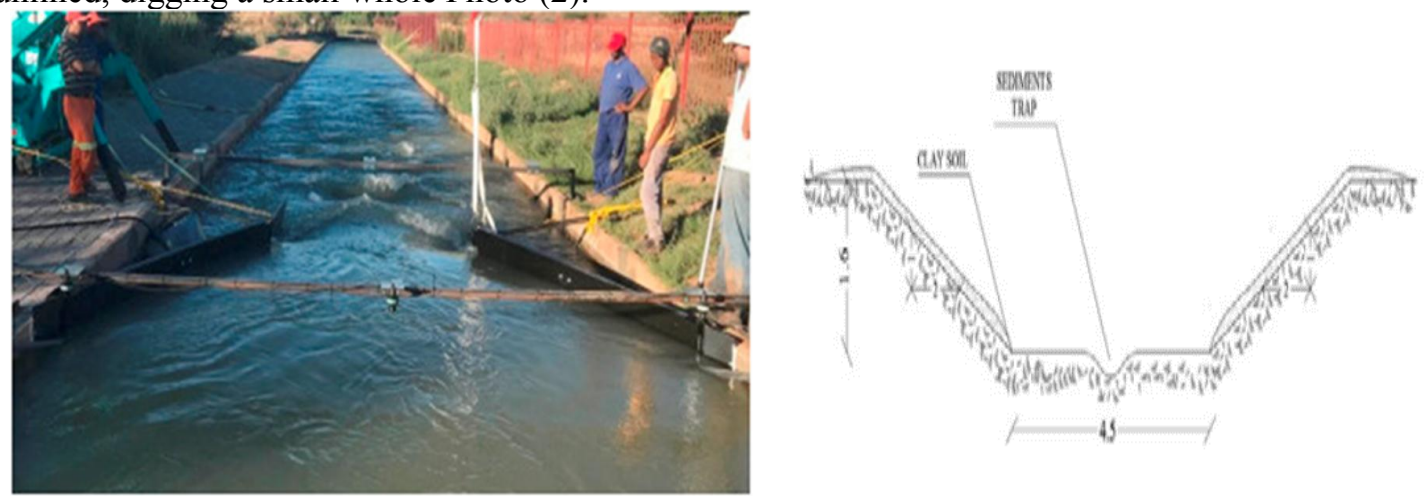

Photo and diagram 2: Illustrates Sediment removal from canal after FAO (2019)

As an ancient field irrigation technology, surface irrigation is most widely used in the world currently, it is the use of ground ditch, border or separate plots as a water interface, Surface irrigation technology has many advantages such as simple field engineering facilities, low investment, low energy consumption, easy implementation and so on (Allen, 1980; Bautista, 2009). In many areas, surface irrigation is still a suitable irrigation method. At present, more than $90 \%$ of the worlds irrigated land applying surface irrigation, especially in China, more than $95 \%$ of the irrigated area using surface irrigation, it can be expected in a long period, and surface irrigation will still account for the leading position in Egypt farmland irrigation (Lanie et al., 2020). Traditional surface irrigation technology has many shortcomings, such as poor irrigation uniformity Kunlun Ding (2019),high water consumption, and deep percolation and so on. In order to conserve water resources, close attention has to be paid to the performance of irrigation systems. Irrigation systems should be evaluated on a regular basis to ensure that the systems are well maintained and are performing according to design Walker, and Lee, (1981), the irrigation system must also be managed correctly and effectively (Ascough and Kiker, 2004). The distribution uniformity of a system must be as uniform as possible to ensure higher yields and the efficient application of water. It should also be included in the calculation of water allocations and the determination of gross irrigation water requirement. Making the water into the field under the action of gravity into the crop farming area soil in order to achieve the purpose of irrigation (Adisu et al., 2018) Photos (3 a and b).

To improve the distribution uniformity of irrigation systems they need to be properly maintained and operated. Especially, overhead irrigation systems need to be operated at the correct pressure and in low wind conditions. The results also show that a well-maintained and correctly operated system can achieve or exceed a distribution uniformity that is considered reasonable and acceptable. An irrigation system can have high application efficiency and have poor DU, (Evans et al., 1985). Even though the 
water is being used efficiently, with minimal spray and/or evaporation loss; large areas of the crop may not be receiving an adequate amount of water. This could lead to crop stress and reduced yields.

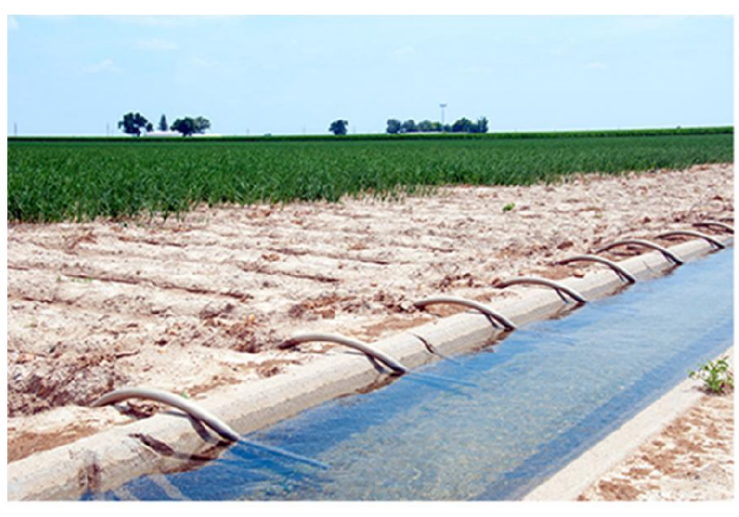

Water is delivered into the field by portable siphon

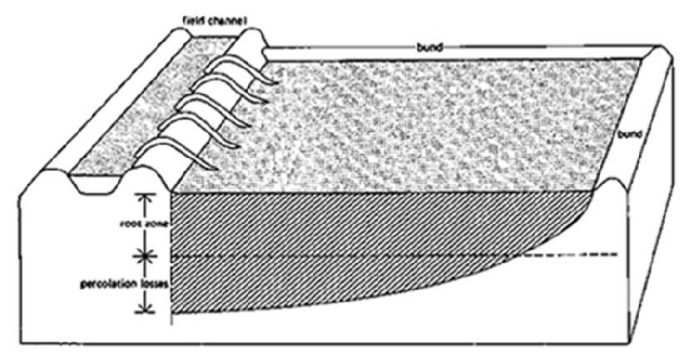

Basin irrigation scheme of water supply with siphons

Photo 3a: Diagram showed Furrow irrigation, with water supplied by siphon tubes from a concrete ditch.

Therefore, the importance of the uniformity should not be ignored, but developing for water saving and increasing the water use efficiency. Smith et al. (2005) reported that agricultural irrigation water for land agriculture were about $70 \%$ of total water consumption for China. Water use efficiency however, is lower, in order to improve the irrigation water use efficiency, an important water saving approach is to improve the surface irrigation technology and increase the field water utilization coefficient (Shen et al., 2007). Similar condition was noticed in Egypt as reported by FAO $(2012,2017)$. In addition, study the precision surface irrigation technology system relying on the development of modern agricultural science and technology, which enhance the developmental level of modern agricultural. Furthermore, improve the performance of surface irrigation systems, achieve the aim of water saving and yield increase. Therefore, it is of great practical significance to study and promote the water-saving surface irrigation technology to alleviate the shortage of water resources (FAO, 2019).
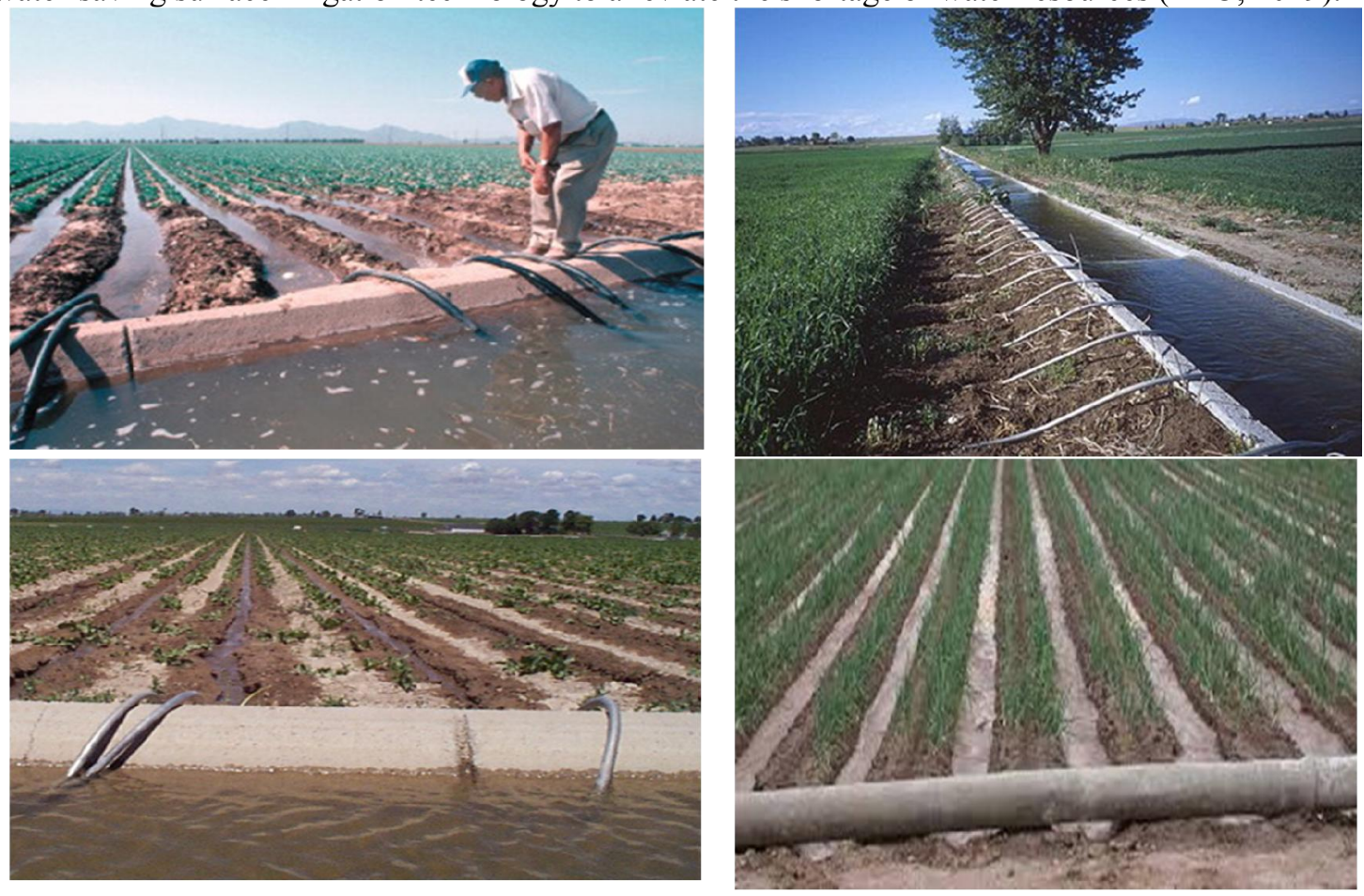

Photo 3b: Furrow irrigation, with water supplied by siphon tubes from a concrete ditch. 


\section{Furrow irrigation}

Surface irrigation (furrow, basin and bay) is a method of irrigation in which water is conveyed on the surface across field by gravity flow while at the same time infiltrating into the soil. Surface systems are the most common in different countries throughout the world (Smith et al., 2005). Furrow irrigation is one of the oldest known techniques of surface irrigation, water is conveyed through small channels with a gentle slope towards the downstream end photo (2). The spacing of these channels generally correspond to the spacing of the crop to be established. This method is popular for the irrigation of row crops. As opposed to furrows, basins are designed to be level in all directions and can be square or rectangular. Earthen banks are constructed around the basin leaving a notch for water inlet.
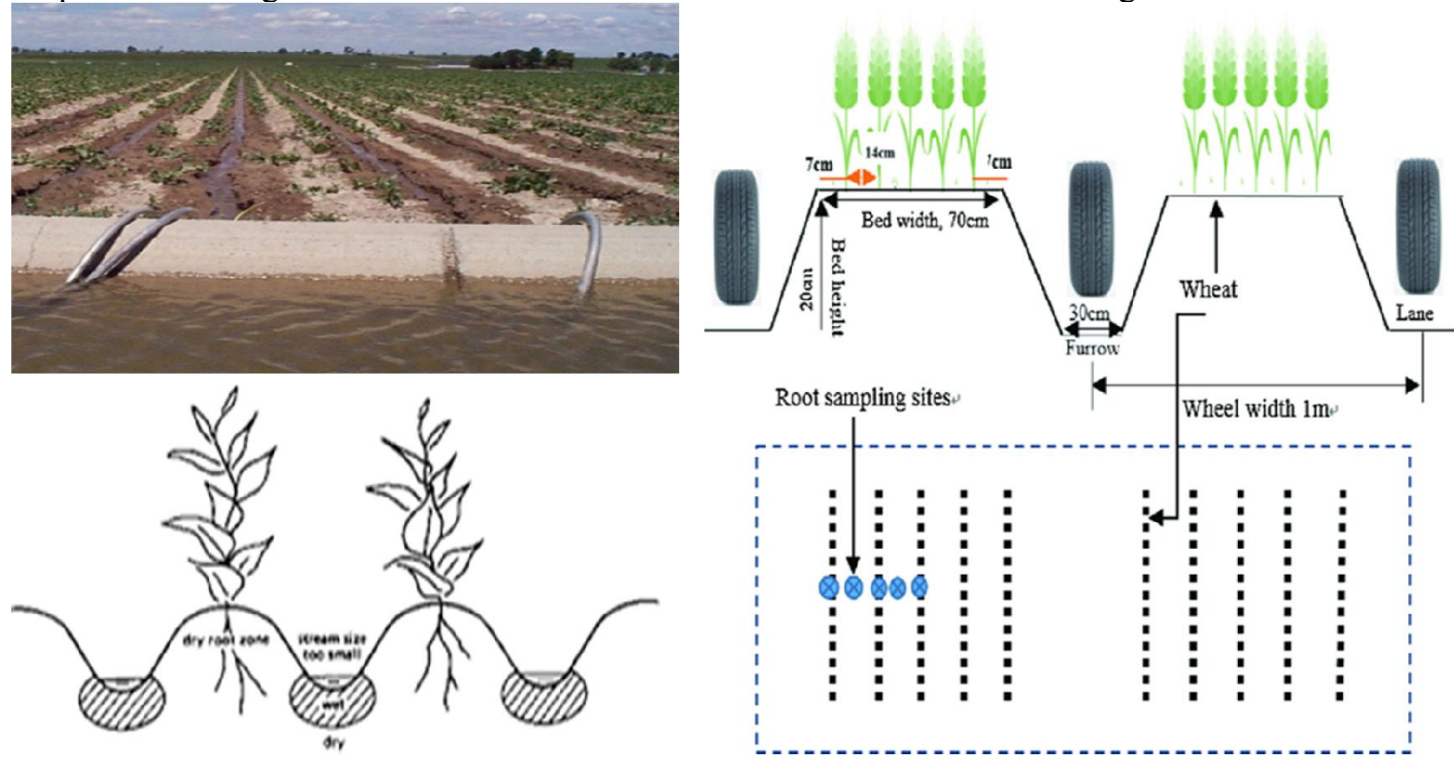

Photo 4: Surface irrigation is conveyed through small channels with a gentle slope towards the downstream

The system has traditionally been used to grow rice. Bays are similar to basins, but have a slight slope and free draining conditions at the downstream end. Bay irrigation is the preferred method for the irrigation of pastures. Surface systems are simple, have low energy consumption and require comparatively low initial capital. However, they are often associated with a high labour requirement and low water use efficiency (Smith et al., 2005). Rising labour costs, the competition for water and the need to conserve the environment has intensified the move to more advanced systems. Automation is one means of ameliorating the problems of high labour requirement and low water use efficiency of surface systems. But the spatial and temporal variability of the soil infiltration characteristics means that each irrigation behaves differently and are therefore difficult to standardize and automate (Walker, 1989). Apart from on-farm automation, many irrigation areas especially, in the southern part of Australia are developing automated water delivery systems. The integration of on-farm and channel control technologies will become a real possibility in the near future. Some of these developments in the irrigation industry have benefited from the Australian Federal and State governments' financing with a precondition that the water saved be surrendered back to the environment (Plusquellec, 2009). Furrow irrigation is at the opposite extreme of the array of surface irrigation configurations from basins photo (5).

Rather than flooding the entire field, small channels called furrows and sometimes creases, rills, or corrugations are formed and irrigated. The amount of water per unit width on a furrow-irrigated field may only be 20 percent of the water flowing over a similar width in a basin. Infiltration is twodimensional through the wetted perimeter rather than a vertical one-dimensional intake. Furrows can be blocked at the end to prevent runoff, but this is not a common practice unless they are used in basins or borders to compensate for topographical variation or provide a raised seed bed to minimize crusting problems. The distinction between a furrowed basin or a furrowed border and furrow irrigation lies in the semantic preference of the user. For purposes of evaluation and design, both of these situations would fall under the term furrow irrigation. 

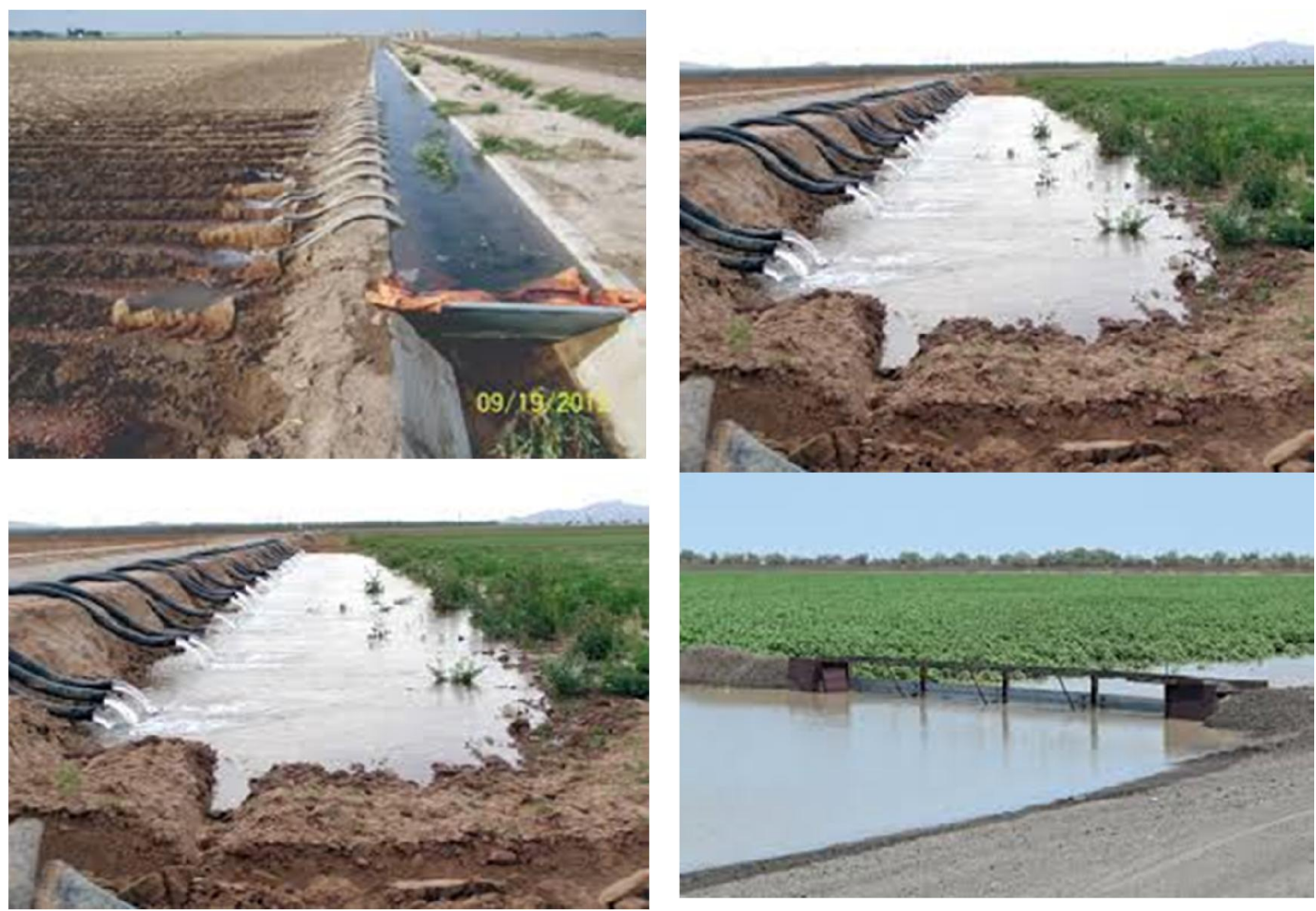

Photo 5: Furrow irrigation is a surface irrigation configuration from basins. After NEH (2006)

Irrigation is crucial for agricultural activities; however, if not managed well, it entails high water losses and can be inefficient in its application. The raised bed system is an improved surface irrigation strategy, which enhances water productivity and makes the application of water in irrigated systems more efficient. The farmers themselves can easily implement it. This practice describes how raised bed systems can be used to improve crop water productivity in summer and winter crops.

Agriculture in Egypt is mainly building upon irrigation water from the Nile. However, available water resources have been reduced by over 80 percent in the last century. New water cannot be captured in the required amount, because only few major resources of renewable groundwater remain untapped. That means practices should be adopted, which have the potential to increase the on-farm water-use efficiency when used for irrigating crops.

Often, over-irrigation leads to a rapid degradation of soils. This is when much more water is needed for the raising of a crop, than the crop actually needs. Water is the limiting factor in Egypt, but the lack of knowledge on how to irrigate, when and how long can tremendously affect the soil and lower its productivity. Consequences might be high salinity of the soil and water logging.

- High salinity of the soil occurs when there is a high evaporation but only a low precipitation. Then, the solute salts solute from deeper soil layers dissolve in the water provided by irrigation and raise to the soil surface while not washed out again.

- Water logging occurs when the irrigated water does not percolate into the soil and remains near the surface as standing water. Most crops wither due the logged water, because the plant roots do not receive enough oxygen.

\subsection{Traditional irrigation practices in winter and summer crops in Egypt}

Most commonly, surface irrigation is practiced in Egypt. Nevertheless, it entails high water losses and is inefficient in its application. Currently, there are applied two traditional irrigation methods for raising winter and summer crops. Usually, winter crops like wheat and berseem are planted on a random broadcasting basis. That means, the seed is distributed randomly by hand or by using a drilling machine. The traditional irrigation practice is of the border irrigation type, which can be best applied at a slope. Irrigation water is then applied through an irrigation channel from the top to the bottom. The borders are long and thin strips, where the water then flows down the slope and irrigates the surface of the crop 
stand. Usually, the application is stopped once the water reaches the end of the border. When using the raised bed-system in winter crops, this border irrigation turns into a furrow irrigation, where water is applied in the bottom of the furrows. This entails the benefit of reduced irrigation time and reduced amount of water used Fig. (5). The typical summer crops are maize and cotton. Traditionally, they are planted in a ridge-furrow system with rows of $0.65 \mathrm{~cm}$ distance apart. One row of plant is planted on the ridges. $22 \mathrm{~cm}$ are left as space between the plants within each row. The furrows are $20 \mathrm{~cm}$ deep and the ends are blocked for preventing runoff from the field. Eventually, the furrows are filled with irrigation water until the water stands at the top of the furrow ridge.

\subsection{Raised-bed system}

The raised bed system is an improved surface irrigation strategy, which enhances water productivity and makes the application of water in irrigated systems more efficient. The farmers themselves can easily implement it. In this system, irrigation water is applied to the bottom of the furrows as presented in Fig. (3). Less water for irrigation is needed, due to the furrows collecting the water efficiently, instead spreading it over the whole surface (border irrigation). Water can be saved, because there is less wetted area than in the traditional surface irrigation methods. When growing winter crops (wheat, berseem), the same amount of seeds is applied, only that they are seeded onto ridges with four rows on each ridge. In the raised bed system, the furrows are wider than in the traditional one. Two furrows are merged; the width of the ridges is double as wide as in the traditional system. In summer crops, like maize or cotton, the rows are widened to a so-called wide furrow system. Instead of a one plant-row per ridge, there are usually two or more rows of plants planted on one ridge. Hence, two furrows are merged to one row. Moreover, this leads to only the half of the furrows and half of the amount of water necessary for irrigating the area.

In the traditional system, there is only one plant row per ridge. The widths of the ridges are half of the size of those in the raised bed system. Thus, there are twice as much furrows for irrigation. However, the same number of crops could be irrigated with half of the amount of water, achieved by the merging of two ridges to one ridge.

\subsection{Economic and environmental benefits}

Raised beds have been proven to increase yields. In both, winter and summer crops, they supported the decrease of the irrigated area, shortened the time needed for irrigation, reduced the amount of water needed and thus reduced costs of irrigation. The water productivity (amount of crop gained per $\mathrm{m}^{3}$ water) was shown to be higher and the yields increased using less water. Applying this practice can help in spending less money for irrigation, while achieving higher yields and increasing the farm income.

\section{For winter crops:}

- The performance of the practice has shown to be more efficient than the traditional border irrigation practice, since less water has to be used to irrigate the entire plot of land. Instead of spreading water throughout the entire surface of the plot, the water is applied only within the furrows, which also means less loss of water through percolation.

- Planting wheat on ridges instead enhances the aeration of the plants and leads to a better growth and better yield.

- Planting wheat on ridges also ensures better use of solar radiation and a more efficient use of fertilizer.

- Ridge planting also enables to better control weeds.

\section{For summer crops:}

The plant density remains the same as in the traditional method, while the number of furrows is halved. Hence, with the raised bed technology considerably less water than with the traditional method is needed for irrigation.

The furrows comprise the same width and depth in both systems. The plant density in the raised bed system remains the same or can even be increased, because more planting space is available, due to fewer furrows in the system. 


\section{Validation of the practice}

The raised bed practice has been tested in Egypt within the project "Community-Based Optimization of the Management of Scarce Water Resources in Agriculture in CWANA - Improving Water and Land Productivities in Irrigated Systems", FAO (2016) The project was based on community participation in the research and development, testing, and adaptation of improved water management options at the farm level. The project consisted of three main components; the Badia Benchmark site in Jordan, with two satellite sites in Saudi Arabia and Libya, the Rainfed Benchmark site in Morocco, with three satellite sites in Tunisia, Algeria and Syria, and the Irrigated Benchmark site in Egypt, with two satellite sites in Sudan and Iraq. The research project was conducted between 2004-2009 by ICARDA's national programs in Jordan, Egypt, Morocco, Algeria, Tunisia, Syria, Sudan and Saudi Arabia. ICARDA's, Integrated Water and Land Management Program was responsible for the project and, together with other ICARDA programs, provided technical support for implementation. The Arab Fund funded the project for Economic and Social Development (AFESD), the International Fund for Agricultural Development (IFAD), the OPEC Fund for International Development (OFID) and the International Development Research Center (IDRC).

\subsection{Development costs}

Furrow irrigation systems are the least expensive surface irrigation systems to develop and maintain primarily because minimal land leveling is required to implement a furrow system and less precise land smoothing is necessary for maintenance.

Jet et al. (2015) reported that, the laser assisted, phase-locked loop (PLL) technique is well known for achieving a high level of accuracy in leveling (Khepar et al., 1982; Jet et al., 2006). The quality of land leveling is important since it affects all the other farming operations. PLL results in a much more level field up to $50 \%$ better than leveling using other techniques. PLL improves irrigation efficiency and reduces the potential for nutrient loss through better irrigation and runoff control. It facilitates uniformity in the placement of seedlings by methods such as a rice trans planter or direct drilling, which helps in achieving higher yield levels. The precisely leveled surface leads to uniform soil moisture distribution, which results in good germination and enhanced input use efficiency and yields, whereas undulated land conditions lead to consumption of more energy and ultimately to a higher cost of production. Use of a soil matric potential approach for scheduling irrigation in rice Kukal et al. (2005) assumes that the soil water deficit at the time of irrigation is uniform over the whole field. PLLcan assist in reducing spatial variability in slopes and moisture conservation of fields. It has been shown to be very effective in enhancing the productivity of a RW system by increasing grain yields of both rice and in the efficient use of irrigation water and other inputs such as fertilizers and pesticides (Jet et al. 2006, 2012, 2009a, b, 2011, 2004). PLL is the process of smothering the land surface within $\pm 2 \mathrm{~cm}$ from the average elevation of land using a laser-guided bucket that scrapes from higher places and spreads onto the low-lying areas. PLL involves altering the fields in such a way as to create a constant slope of $0 \%$ to $0.2 \%$. Before running the laser leveler, the field is surveyed at a $3-5 \mathrm{~m}$ distance for recording the elevation. The elevation points are averaged to the desired elevation for leveling the field. The average elevation value is entered in to the control box for controlling the scrapper at this elevation point. Rudragouda et al. (2012) reported that slopes of the field before TLL in the X and Y directions were $0.29 \%$ and $0.47 \%$, respectively, and after leveling slopes were reduced to $0.20 \%$ and $0.23 \%$.

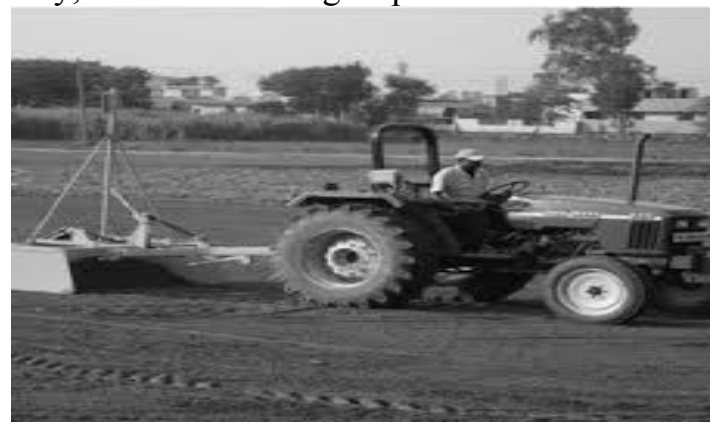

Photo 6: The most commonly used four-wheel, tractor-drawn, laser-assisted precision land leveler in operation. After Jet, et al. (2015) 
The furrow themselves can be formed with cultivation equipment at the time of planting. Furrow irrigation using siphon tubes from a field while less expensive to implement, furrow systems are substantially more labor intensive than basins photo (7).
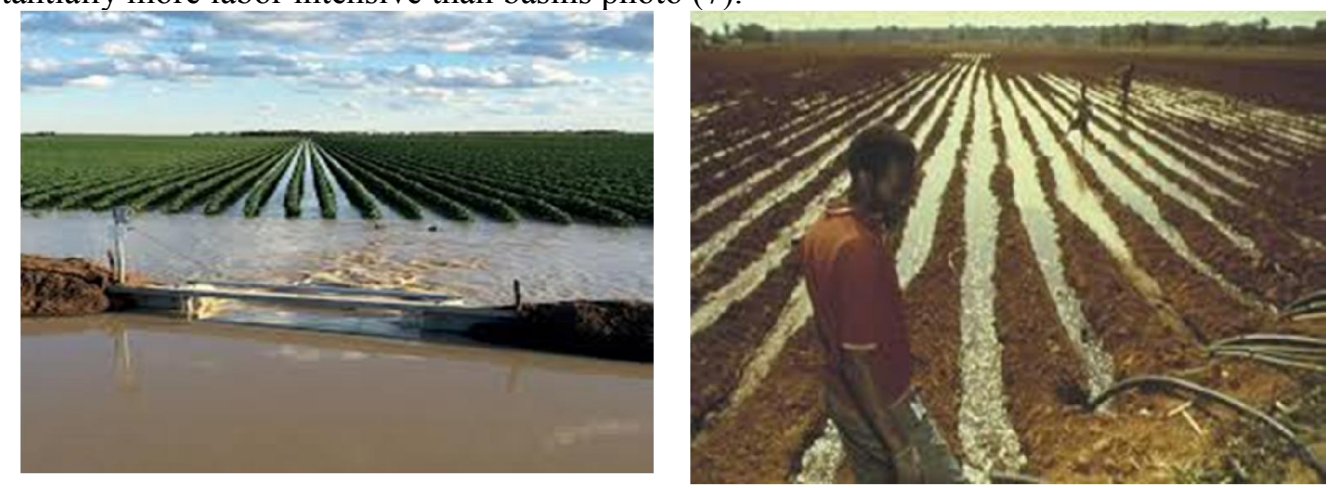

Photo 7: Furrow irrigation system using siphon tubes more labor than basins

Variations in individual flows, slopes, roughness, and intake alter the advance rate of each furrow, and there are often substantial differences in how long it takes the water to reach the end of the furrow. In addition, some furrows are compacted by the wheel traffic of planting and cultivation equipment and have substantially different characteristics than non-traffic furrows. Irrigators compensate by adjusting the furrow flows and, thereby, need to be at the field longer. Further, they also have to assess how long to allow the water to run off the field before shutting it off, as opposed to shutting the flow off in a basin when the correct total volume has been added to the field. Because most furrow systems allow field tail water, they are seldom as efficient as basin systems and, thereby, require more water per unit area. Measures such as the capture and reuse of tail water can be employed to increase efficiency. Another alternative is a concept called cutback that involves reducing the furrow inflow after the flow has reached the end of the furrow. Surge flow and cab legation systems are examples of automated cutback systems.

\subsection{Field geometry}

Furrow irrigated fields generally have slopes in both the direction of the flow and the lateral direction. These slopes can vary within a field; although, the slope in the direction of flow should not vary significantly unless it is flattened at the end of the field to improve uniformity. Using of contour furrows to irrigate irregularly sloped fields. The topography of an individual field is an important consideration in determining the suitability of furrow irrigation. The topography must be, such that within the grade limitations for the climatic area the rows can be laid out on a continuous grade. If land leveling is required to provide the design grade, the topography must be such that leveling does not expose unproductive soil or that the cost of leveling is not excessive. The topography must not be so steep that it exceeds the allowable corrugation grade or prohibits installation of graded contour furrows that meet the design grade and cross-slope criteria. One of the major advantages of furrow irrigation is that undulations in topography have less impact on efficiency and uniformity than they do in either basin or border irrigation.

\subsection{Soil characteristics}

Furrow irrigation is suitable for most irrigable soils if the soil depth and the surface topography permit the needed land leveling at an economically feasible cost and without permanent reduction of soil productivity. This method is best suited to medium to moderately fine-textured soils of relatively high available-water-holding capacity and intake characteristics that provide both lateral and vertical water penetration. These soil characteristics permit uniform irrigation with a minimum of water loss to deep percolation or surface runoff from the end of the rows. In coarse-textured sands and loamy sands, irrigation water moves mainly downward and very little laterally Fig. ( 8 a and b). 


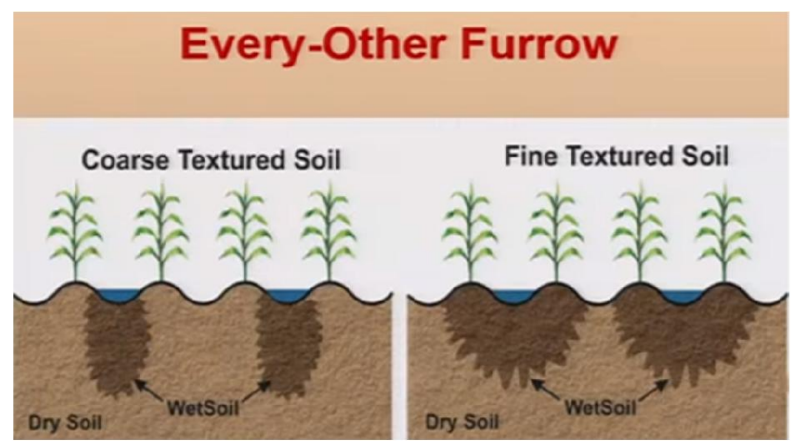

Fig. 8a: Every-other irrigated furrow infiltration patterns on coarse and fine textured soils.

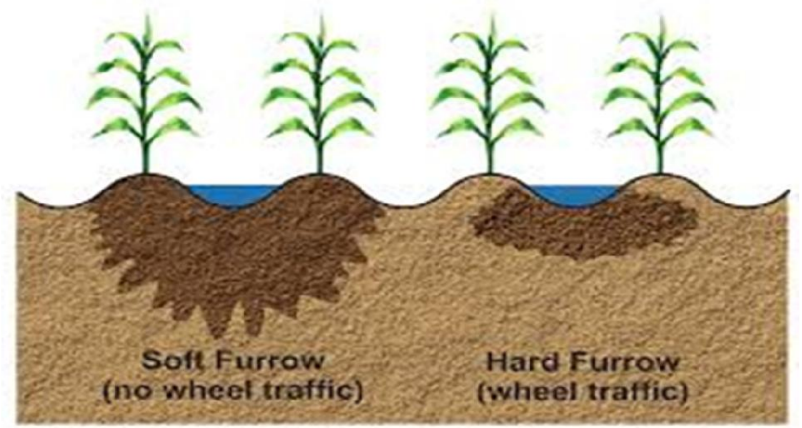

Fig. 8b: Differences in water infiltration patterns under non-wheel track and wheel track furrows.

Fig. ( 8 a) illustrates that, when irrigation is required, it may be important to irrigate the entire field as quickly as possible. Irrigating every other furrow supply water to one side of each furrow ridge, but the wetting pattern is usually much more than that. This technique lets the irrigator apply water to more surface area in a given amount of time than does irrigating every furrow. Research indicates that every-other-furrow irrigation results in yields comparable to those achieved when every furrow is irrigated. With every-other-furrow irrigation, water applications may be reduced by 20 to $30 \%$. Onehalf as compared to irrigating every furrow, because of increased lateral infiltration when watering every other furrow, do not reduce infiltration. Lateral water movement in the field can be checked using a soil probe in the dry rows. Fig. (8a) shows the infiltration pattern for different soil textures. On coarser textured soils, the wetting pattern does not move as far laterally as it does on medium- and fine-textured soils. In this case, every-other-row irrigation may be effective only on narrower row spacing. An added benefit of irrigating every other furrow is that by applying less water per irrigation, more storage space is available for precipitation after an irrigation event.

Fig. $(8$ b) illustrates that Soil compaction can significantly influence furrow irrigation effectiveness. The best example of this is the obvious difference in irrigation water advance rates between "soft" and "hard" rows. In "hard" furrows, those compacted by machinery traffic, infiltration is slow and advance rates are very quick. Even if the flow in the hard furrow is reduced so that water advances at the same rate as the soft furrow, infiltration in the soft row may still be 50 to $100 \%$ more than in the hard furrow Fig. $(8 \mathrm{~b})$. This row-to-row difference complicates water management, especially for every-other-row irrigation. It is important to check water penetration after an irrigation to see if the hard rows got wet deep enough. If not, the "dry" furrows and "irrigated" furrows should be alternated from one irrigation event to the next. Watering only soft rows may be one option to avoid the hard row problem. However, this is not an option where dual wheeled equipment is used or where grain carts have compacted rows during harvest. In those cases, not every other row will be soft. In general, extra runoff from hard rows is not a major problem if a reuse system is used. When no reuse system is in place, the extra runoff increases losses and becomes a headache with blocked-end furrows. More attention should be paid to checking rows and adjusting gates if a large build-up of runoff water behind the end-of-field dike is to be avoided.

Efficient furrow irrigation on these soils requires a short run, a short application time, relatively narrow row spacing, and a small depth of water application. These severe limitations result in high labor 
and operating costs; therefore, furrow irrigation is not generally recommended on these soils. Finetextured, very slowly permeable soils present a different problem. Water must be impounded, or a very small stream applied for long periods to obtain the desired intake. Unless a small stream is used, excessive surface runoff will require extensive tail water recovery or safe disposal facilities. Many of these soils crack before they reach the moisture level at which irrigation is needed. These cracks frequently make it difficult to confine the irrigation water within the furrow. The restrictive features of these soils should be carefully considered before recommending any type of furrow irrigation. Corrugation irrigation is generally unsuitable on these types of soils. Furrow irrigation generally is not recommended on soils containing high concentrations of salts. In most irrigated soils, salts are supplied from the waters being used and/or from the parent materials in which the soils formed. The irrigation water absorbs the salts from the soil; through capillary movement and subsequent evaporation of the water, the salts are concentrated in the surface soil of the furrow ridge where crop roots are most likely to be.

Furrow irrigation can be practiced on nearly all soils, but there are two important limitations. First, the risk of erosion is higher in furrow irrigation than in either basin or border irrigation because the flow is channeled and the flow velocities are greater Photo. (9).
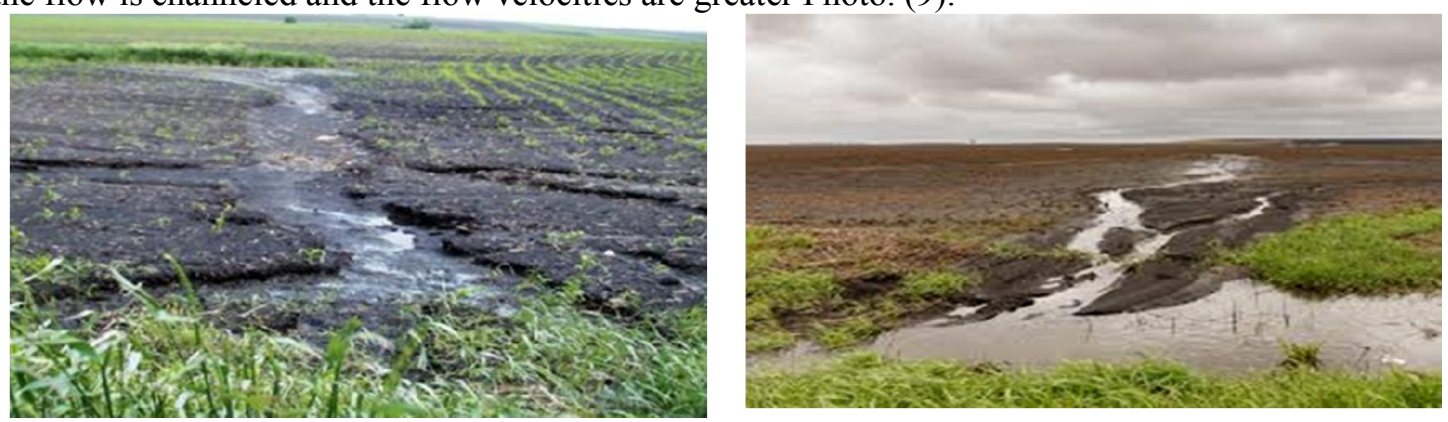

Photo 9: Furrow irrigation can be affected on soil erosion

Secondly, since the furrow actually wets as little as 20 percent of the field surface (depending on furrow spacing), applying relatively large depths of irrigation water particularly in the heavy soils can require extended periods of time and will result in low efficiencies. A 10 or $15 \mathrm{~cm}$ irrigation application is common in basin and border irrigation but would not be feasible with a furrow system on a particularly heavy soil. Furrow irrigation is more impacted by soil cracks than borders and basins since the cracks often convey flow across furrows. Restrictive layers due to their inherent two-dimensional wetting patterns probably less impact furrows. Water management in surface irrigation systems is difficult to manage at consistently high levels of performance (efficiency and uniformity) because the basic field characteristics change from irrigation to irrigation, crop to crop, and year to year. For example, the soil intake changes dramatically between the first irrigation following cultivation and the next. The field is also smoother, as long as the crops do not grow in the flow path, but will become rougher as the season progresses.

\subsection{Crops}

Furrow irrigation can be adapted for nearly all irrigated crops except those grown in ponded water, such as rice Photo (10).
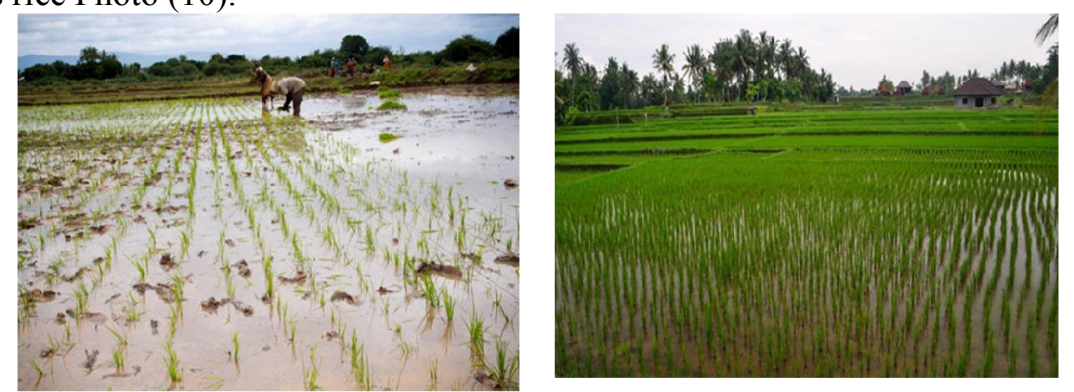

Photo 10: Furrow irrigation system can be adapted for irrigated crops except those grown in ponded water, such as rice 
Tillage, harvest, or other cultural practices associated with the site may be so restrictive; however, some other method of irrigation should be selected. Furrows are particularly suitable for irrigating crops subject to injury if water covers the crown or stems of the plants.

\subsection{Water Supply}

The quantity and quality of the water supply determine its suitability for use in furrow irrigation. Water Quantity Furrow irrigation can be used with any amount of water (either rate-of-flow or volume) if the acreage to be irrigated does not exceed the acreage for which the supply available can meet the needs of the crop to be grown. If the systems are properly designed and water management is good, furrow irrigation can be as efficient as any other method of water application except a properly designed and managed trickle system. For maximum use of a limited water supply, alternate-row irrigation or other procedures can be used. Furrows are well suited to nearly any irrigation delivery rate because the number of rows irrigated in a set can be varied as needed. Water quality irrigation water may be of good quality or it may contain considerable amounts of colloidal material or various salts and minerals Maas, (1990) Photo (11). Furrow irrigation can be used if the water quality is good and, on some soils, if the Water contains moderate amounts of colloidal materials. These colloidal materials will be deposited in the furrows and may materially decrease the intake rate of the soil. This can be to the irrigator's advantage when irrigating high-intake-rate soils such as sands. The colloidal materials may increase soil fertility, may make these soils easier to irrigate by allowing a longer furrow, and increased application time. On other soils, these materials may accumulate on the surface, making tillage more difficult and required more frequently. Most irrigation water contains appreciable amounts of various salts or minerals that can be beneficial or harmful, depending on the kinds being carried. Plant use of soil moisture contributes to the accumulation of salts as presented in Photo (11).

Because most plants can select nitrate, potassium, and phosphate ions from the soil solution, these ions are seldom found in appreciable amounts in saline accumulations. The plants in very limited amounts, however, take up sodium, sulfate, and chloride ions. Evaporation from the soil surface and selective use by the plants cause these salts to accumulate in the furrow ridge. Most of the crop roots develop in the ridge where salts accumulate; therefore, furrow irrigation is not suitable if the water supply contains considerable amounts of detrimental salts such as sodium.

Surface irrigation can be configured to work well within a range of slopes between 0 and 0.5 percent. If a flatter slope is needed to control erosion at the end of a sloping field Adisu (2018), Abebe et al. (2016), Ferna et al. (2004), Photo (13).
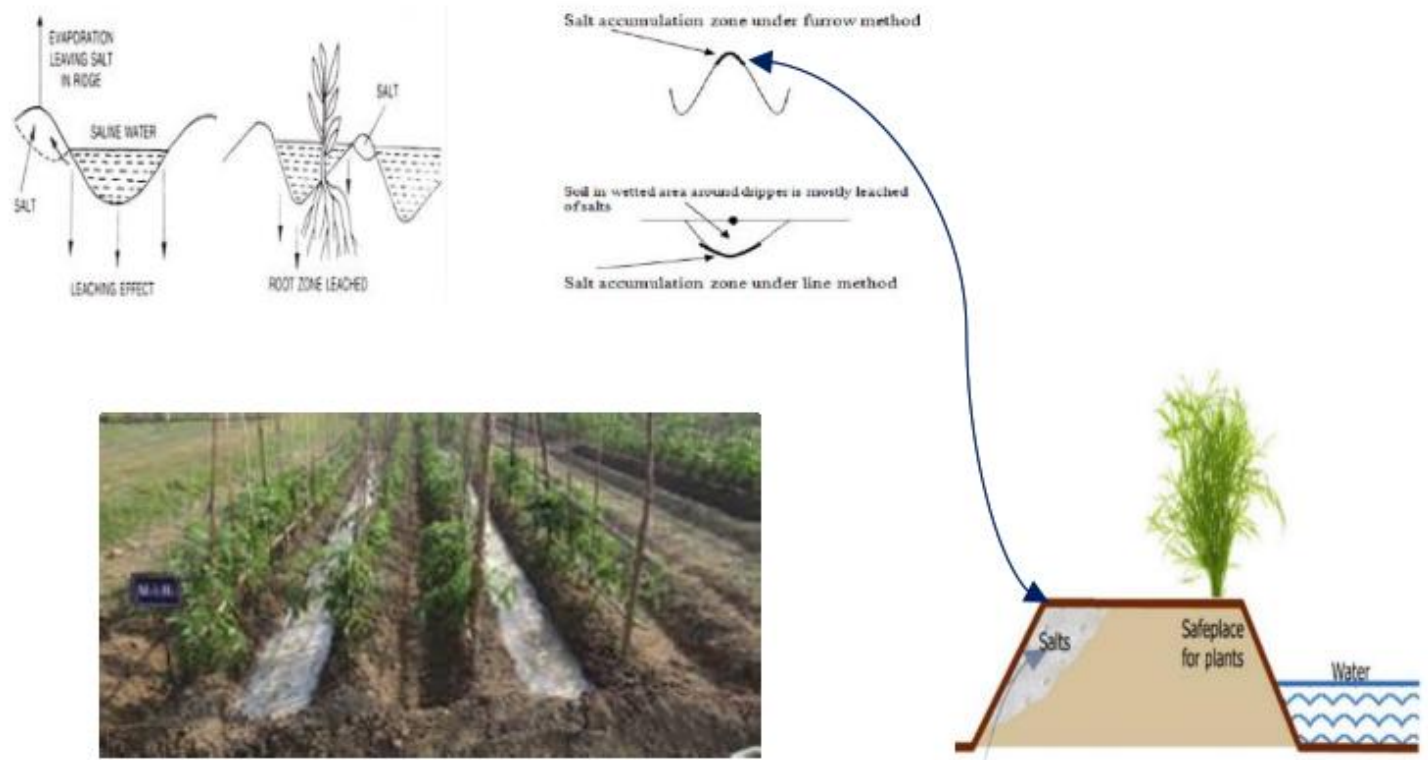

Photo 11: Accumulation of salts in the furrow ridge due to evaporation from soil surface. 

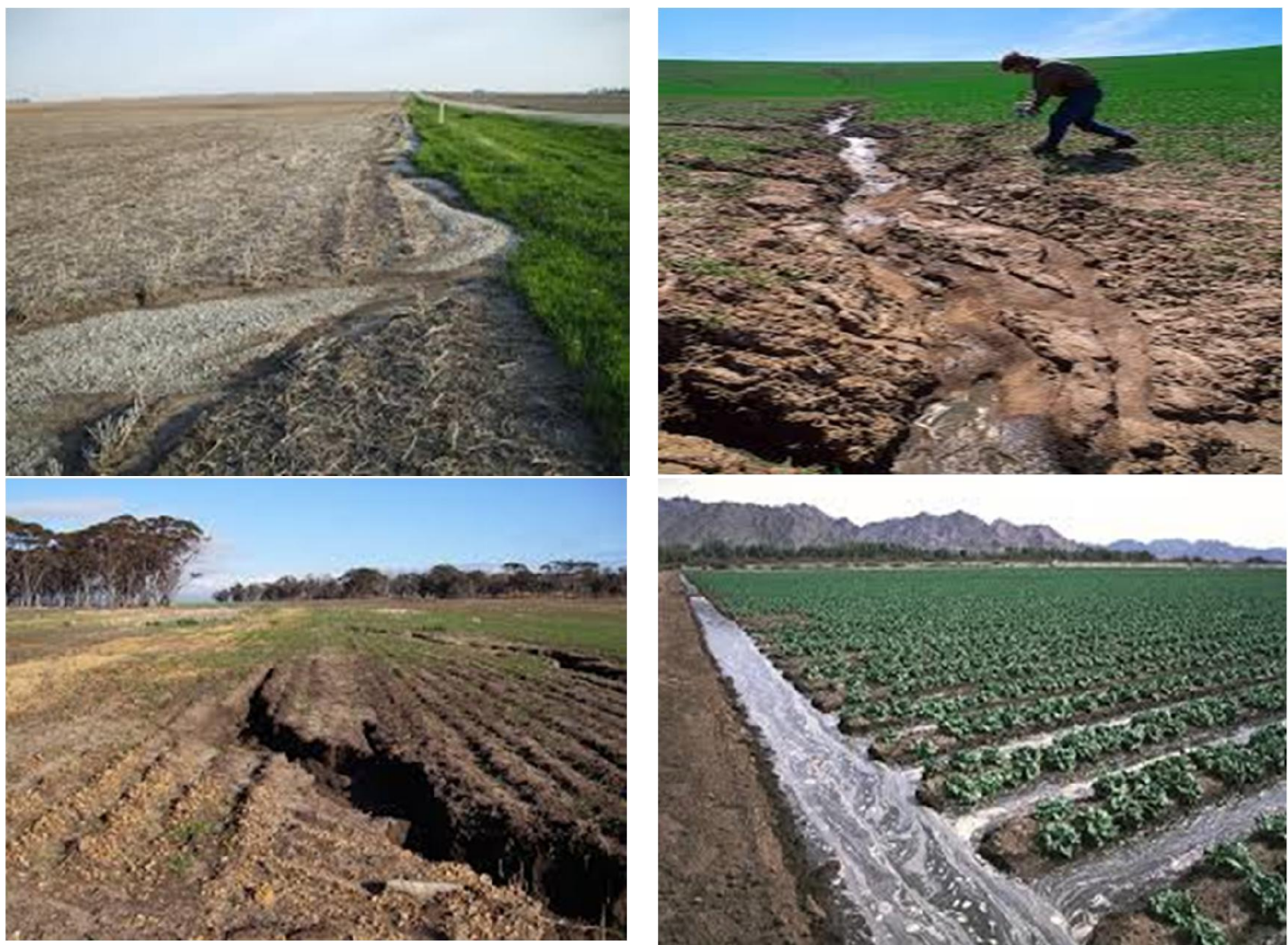

Photo 12: Furrow Irrigation cause erosion on irrigated soil

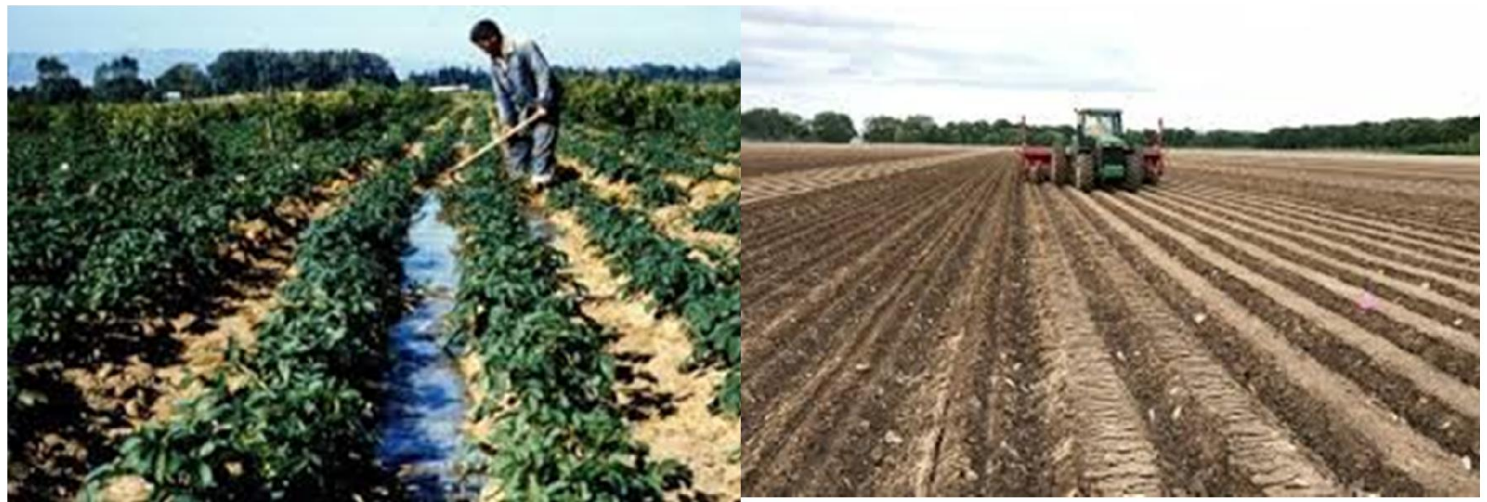

Photo 13: Kinds of furrow irrigation systems

Flattening the last quarter of a field's slope is easily accomplished with modern laser guided land leveling equipment and need not be prohibitively expensive. Surface irrigation performance can always be improved by accurate leveling and smoothing of the field surface. As noted previously, most irrigators consider precision land grading as the best water management practice. Furrowing borders or basins also reduces the effect of topographical variations. Some soils are too coarse textured for efficient surface irrigation, but practices aimed at incorporating crop residues and animal manures not only change intake rates, but also improve soil moisture-holding capacity. When water advance over a freshly cultivated field is a problem because of high intake, a limited discharge, or an erosion problem, the surface is often smoothed and compacted by attachments to the planting machinery.

\section{Kinds of furrow irrigation}

There are four kinds of furrow systems:

Level Limitations furrows graded straight furrows, graded contour furrows, and corrugations. 
Each system requires specific designs and layouts. The suitability of each depends on the topography, kind of soil, kind of crop, cultural practices, and climatic factors photo. (14).
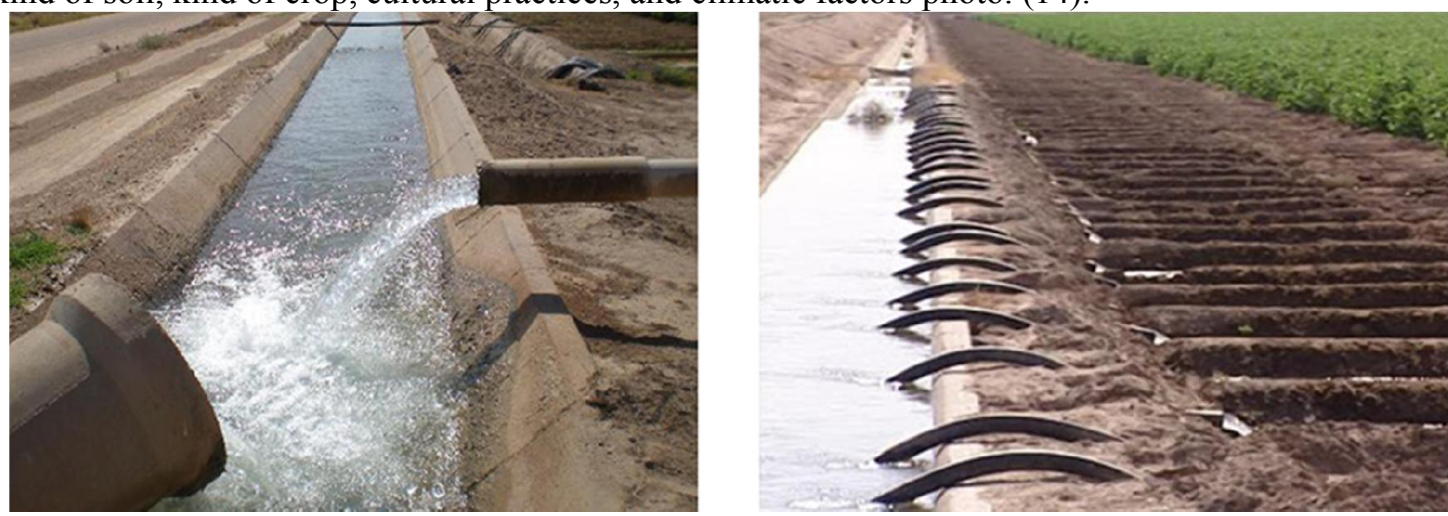

Photo 14: Represents farm ditch and underground pipelines for water conveyance to furrow irrigation

\subsection{Level Furrows}

Level furrows are small irrigation channels, with blocked or diked ends laid out with little or no grade.

Farm ditches for irrigation are open channels used to carry irrigation water to the field where crops are grown. In order to prevent ditch erosion, ditches have to have concrete linings. Otherwise, they can be difficult to maintain and disturb proper water conveyance. Although concrete farm ditches are not always the best solution, because they can obstruct the use of farm equipment. Farm ditch system includes the following structures that deliver water directly to the furrows:

- Flumes for water delivery used where ditches are not practical

- Inverted siphons carry water under depressions, roads, or other obstructions

- Culverts at ditch grade commonly used to carry water under farm roads

- Siphon tubes used for controlling the flow of water into each furrow

- Spiles to distribute water from a ditch into furrows, permanently set on the bank of the head ditch

Water can be delivered to the furrow by pipelines. Irrigation pipelines can be placed on the surface, underground or like a combination of both. Both types have their advantages and disadvantages, and their usage depends on the farmer itself. To some farmers, surface pipes are better because they can be moved to another location, but their relocation requires labor and pipes can be damaged Yadav et al., (2000).

Generally, require extensive land preparation and careful water management for successful operation. Irrigation water must be applied rapidly, using a stream as large as the furrow can contain, until the designed volume is applied. The ponded water stands at a uniform depth in the furrow until it is absorbed by the soil Sikka (2008). Lateral or capillary movement of water throughout the soil distributes the water to areas between the furrows. Adaptability The level furrow is best suited to soils with a moderate to slow intake rate and moderate to high available-water-holding capacity.

Topography must be relatively flat with smooth, uniform slopes. The crops most easily irrigated by level furrows are those grown in rows on beds between the furrows, because relatively large channels must be maintained to provide the necessary capacity. Level furrows are suited to all climatic areas except the humid area where a minimum grade is required to achieve the surface drainage needed to prevent crop damage or water logging of soils. The amount of water applied can be adjusted to the needed seasonal variations by changing the duration of application or the size of furrow stream, or both. No change in layout is needed. Efficient application can be obtained if the system is properly operated. No irrigation water need be lost through runoff. Maximum use can be made of rainfall even when the intensity of storms exceeds the soil intake rate. Provisions for disposal or reuse of tail water are not needed. Water can be introduced at both ends of the furrows so that the furrow length can be twice the design length, which allows more efficient use of farm equipment.

This method is well suited to automation for approximately one-half the volume of the net irrigation application. The irrigation application time must be short; therefore, frequent change of sets is required. The surface topography, furrow shape, and cross section must be carefully maintained. The 
farm operator must know about these specific needs and requirements for successful operation of the system.

\subsection{Graded straight furrows}

Graded straight furrows are small irrigation channels on relatively flat land laid out either in the direction of or across the slope of the land photo (15)

They are constructed in a straight line, preferably parallel to a field boundary, and have a continuous, nearly uniform slope in the direction of irrigation. The length of time that water must flow in the furrows depends on the amount of water required to refill the root zone, the intake rate of the soil, and the rate of lateral spread of water in the soil. For most soils, the initial irrigating stream must greatly exceed the intake rate to provide an adequate advance rate that will result in a reasonably uniform intakeopportunity time along the furrow. When water reaches the lower end of the furrow, the flow rate must be reduced to prevent excessive runoff or provisions must be made to dispose of the tail water safely or to recover and reapply it. Even where' the streams are cut back; an appreciable amount of tail water will collect.
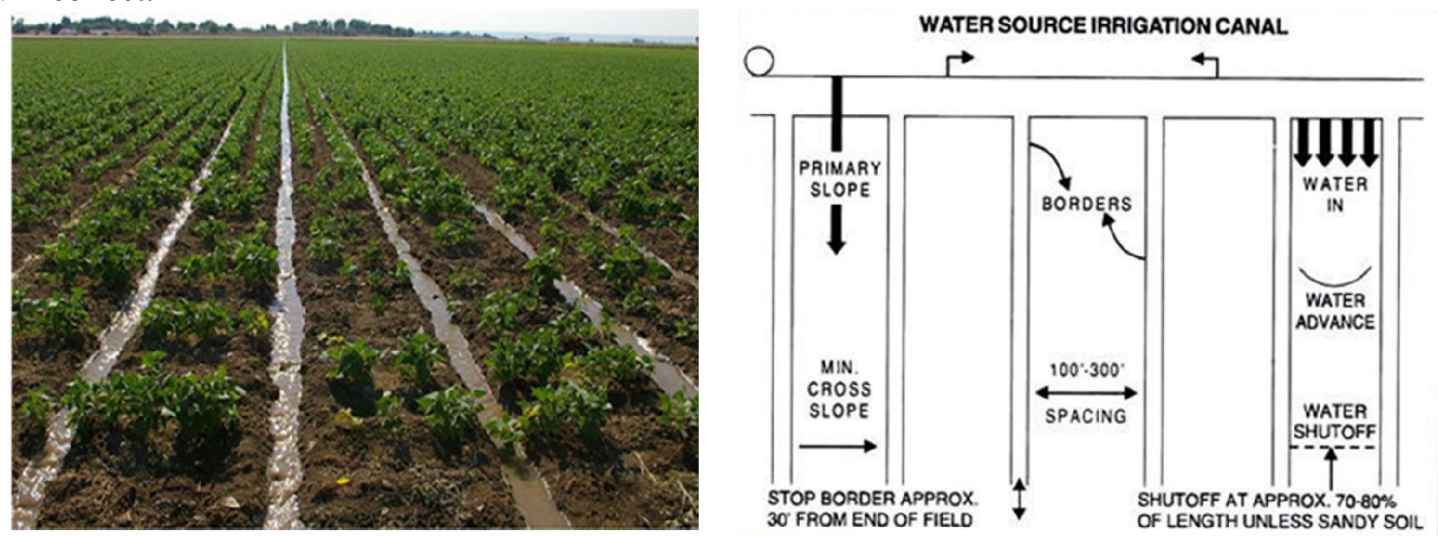

Fig. 15: Straight furrows are small irrigation channels on relatively flat area

Therefore, a tail water recovery system and provisions for safe disposal according to state regulations are normally integral parts of a graded furrow system. Adaptability Graded straight furrows can be used to irrigate all cultivated crops planted in rows. Graded furrows can be used on all soils except sands that have a very high intake rate and provide poor lateral spread of is not uniform in one direction, the benches may suited to sites where land slopes are at least 0.1 have one or more turns. To permit turning large percent but no more than $3 \%$ in arid areas and equipment, the turn angles should not exceed 30 no more than $2 \%$ in semiarid areas, $1 \%$ degrees. The turns in adjoining benches should be in sub humid areas, and 0.5 percent in humid areas. Along the same radii path to eliminate the need for on smooth, uniformly sloping fields with slopes of three irrigating point rows as presented in photo (15). Limitations Labor requirements are high unless the system is automated. Flow into each furrow must be carefully regulated to achieve uniform water distribution and minimum waste. Fields must be carefully leveled and facilities for collecting and disposing of surface runoff must be provided. Small irrigations especially needed for seed germination or for shallow-rooted crops are difficult to apply efficiently. Uniform application is difficult on soils with high intake rates; Land slopes must be relatively flat and uniform to permit installation within design limitations.

\subsection{Graded contour furrows}

Graded contour furrows are small graded irrigation channels on fields with uneven or warped Surfaces where it generally is not practical to use straight furrows within permissible grade limitations Photo (16). The furrows are curved to fit the general contour of the land and have enough grade to carry the irrigation stream to the end of the furrow. The grade must be somewhat variable to prevent creating. Graded contour furrows are small graded irrigation channels with uneven or warped surfaces (Gharbi, 1984; Walker, 1989). They are mainly used on surfaces where it is not practical to use straight furrows. The furrows are curved to fit the field contour. This type can be used on all slopes and soil types except sandy, and soils that crack easily when dry (Marr, 1967; Ismail and Westesen, 1984; Hart et al., 1980) 


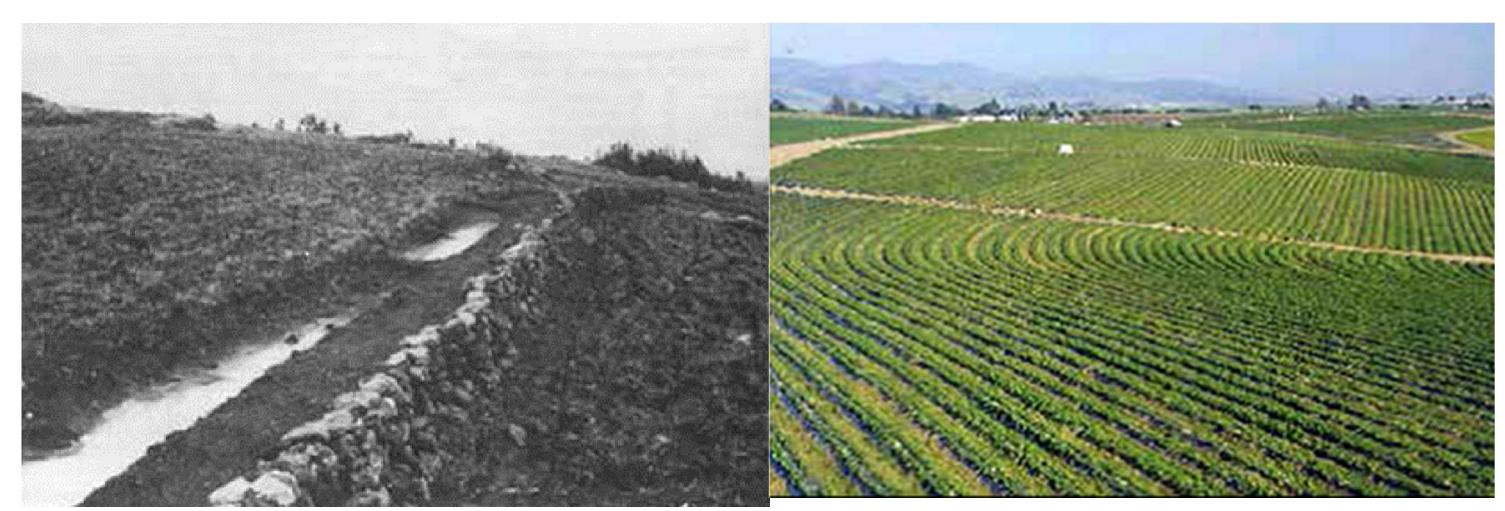

Photo 16: Crops irrigated with type of furrow irrigation system graded contour and other contour bands in Ethiopia within the basin and stone reinforcement of the bank

\section{Alternative furrow irrigation technology}

Alternate furrow irrigation is a kind of controlled root divided alternative irrigation technology, the principle is that a part of roots in the drought stress when irrigation and produced the root signalabscisic acid control stomatal aperture, while the other parts of the root supply moisture for leaf to keeping the leaves do not occur water deficit avoid drought to cause injury, beneficial to the growth and development of crops. Alternate control to subject some roots to a certain degree of water stress, improve soil permeability, conduction ability and absorption function (TaiSheng et al., 2007). Research showed that alternate furrow irrigation amount more than $30 \%$ per ditch compared to flood irrigation, but the total amount of irrigation save more than $30 \%$, and it can save water more than $15 \%$ compared to conventional furrow irrigation, and yield was significantly higher than that of conventional irrigation under the same irrigation level, the yield increased 2.85\% 3.96\% (Yinghua and Shaozhong, 2000).

\subsection{Surge flow irrigation technology}

Surge flow irrigation is an advanced water-saving surface irrigation method which irrigating water intermittently and alternately to border or ditch according to a certain period, until the completion of irrigation. It has the characteristics of water saving, energy saving, labor saving and high irrigation quality compared to traditional surface irrigation method Qunchang et al. (2002).Yuliang Fu established the intermittent infiltration of surge irrigation model based on the theory of Green-Ampt and Philip infiltration model, the mechanism of intermittent infiltration of surge irrigation is described accurately by the mathematical model of soil volume moisture content increment and cumulative infiltration, which provides a theoretical basis for rational design of surge irrigation technology Yuliang et al., (2016). Xiulu Sun studied the spatial distribution and space distribution of soil water and nitrogen in continuous border irrigation and surge flow irrigation, concluded that the distribution of water and nitrate nitrogen in soil was better than continuous irrigation, surge flow irrigation can play a role in water and fertilizer conservation to some extent under the condition of irrigation and fertilization Xiulu et al. (2015).

Surge irrigation technology has the characteristics of energy saving and solve the problem of long furrow irrigation, it is easy to master and apply. Therefore, surge irrigation is very suitable for the existing social, economic and technical status of irrigation areas in China. It is necessary to vigorously promote the surge irrigation for water saving and ease the shortage of water.

\subsection{Precision surface irrigation technology}

From the trend of irrigation development in the world, surface irrigation is still the main irrigation method adopted worldwide for a long time, but irrigation management technology need strengthened. In the process of improved surface irrigation technique, it is necessary to inject some new technology such as laser control technology, GPS and GIS technology, computer simulation technology and automatic control technology to improve the irrigation system performance and effective use of water 
resources, achieve significant effect of water saving, increasing production and protecting environment (Yuliang et al., 2016).

\subsection{Laser controlled land-leveling technology}

Laser leveling technology is the most advanced land leveling technology in the world, it has been widely used in developed countries at present, and our country is still in the stage of introduction, demonstration and popularization. Based on laser control technology, global positioning system (GPS) and geographic information system (GIS), realize the achievement of laser control land precision leveling technology. Related research results showed that laser controlled leveling technology can effectively improve the micro topography of the field and the field leveling accuracy, come to effectively use of irrigation water, and achieve precision surface irrigation. In 2006, the application of laser leveling technique in Yellow River irrigation area in Ningxia indicated that the leveling accuracy the spatial distribution and space distribution (Sd) of paddy field decreased from $4.27 \mathrm{~cm}$ to $1.50 \mathrm{~cm}$ adopted laser control leveling, the average relative improvement was $64.03 \%$, and the spatial distribution and space distribution (Sd) of dry land decreased from $7.24 \mathrm{~cm}$ to $1.91 \mathrm{~cm}$, the average relative improvement was $71.04 \%$, rice water-saving was $30.71 \%$, and yield increased by $23.41 \%$ (Gao et al., 2012). In year 2011-2012, laser leveling technologies were popularized in cotton and cumin planting in Jiuquan city, water saving rate was from $26.2 \% \sim 40.5 \%$, the economic benefits reached from $18.3 \% \sim 61.3 \%$ comparing to the local traditional ground scraping method (Shen et al., 2006). At present, the difference of surface elevation is generally in the range of $2 \mathrm{~cm}$ after using laser control leveling technology, which has a better effect of leveling land (Gao et al., 2012). Laser controlled technique can significantly improve the utilization efficiency of irrigation water, increase economic, social and environmental benefits, and needing vigorously popularization and application in agriculture in future.

\subsection{Real feedback control technology of precision surface irrigation}

The study of real time feedback control technology on surface irrigation is an important aspect of the precision surface irrigation. It is a method of direct or indirect inversion to calculate the effective average soil infiltration parameters and the field roughness coefficients in real time status based on the observed data of surface water flow during a particular irrigation period. At present, the method to estimate the effective average soil parameters is generally divided into two ways: one is directly estimate parameters based on the principle of water balance, the other way is indirectly estimate parameters according to the matching degree between observed and simulated data of surface water flow. In these two methods, Kostiakov empirical formula $(I=k \cdot t$ a or $I=k \cdot t a+c)$ with two parameters $(\mathrm{k}, \mathrm{a})$ or 3 parameters $(\mathrm{k}, \mathrm{a}, \mathrm{c})$ is usually used to describe soil infiltration characteristics, and the Manning formula $(\mathrm{Q}=1 / \mathrm{n} \cdot \mathrm{A} \cdot \mathrm{R} 2 / 3 \cdot \mathrm{i} 1 / 2)$ is used to describe the roughness coefficient(n). Many studies showed that Kostiakov empirical infiltration formula is a widely adopted method at present (Shen et al., 2007). The soil characteristic parameters estimated by Kostiakov formula can make the irrigation efficiency of surface irrigation system under precision land leveling conditions, designed for real-time feedback and control during the process of surface irrigation can reach above $85 \%$, it can effectively improve the design and evaluation method of the surface irrigation system and greatly improve the performance of surface irrigation system (Bautista et al., 2001). With the development of computing technology, using mathematical model to analyze the whole process of surface irrigation has become an important means of fine surface irrigation technology (Raine et al., 2001).

\section{Maximization, minimization of losses of fertilizers under furrow irrigation system}

For maximization fertilizer application efficiency and minimization, the losses of fertilizers through runoff and leaching. Several strategies should applied to evaluate the uniformity of fertilizer added through fertigation systems in different soil textures in blocked-end and free-draining furrow irrigation regimes, assessment the losses through runoff and deep percolation, and finally to calibrate and validate a physically based model simulating overland water flow and solute transport for assessing and managing surface fertigation practices. Application of fertilizers with irrigation water is a costeffective and efficient method for fertilizer application to enhance crop production and reduce potential environmental problems in comparison to conventional methods. The distribution uniformity of fertigation and fertilizer losses through runoff and deep percolation were evaluated at field scale in 
different furrow irrigation regimes and soils. A numerical fertigation model was calibrated and validated. Fariborz Abbasi et al. (2012) study the distribution of potassium nitrate injected during the first half of the irrigation $(\mathrm{FH})$, in the second half $(\mathrm{SH})$ and during the entire irrigation event $(\mathrm{T})$ in three texture soil under free-draining and blocked-end conditions with a cutback method. They calculate the distribution uniformities of low half (DULH) and low quarter (DULQ) of water and fertilizer to evaluate different fertigation scenarios. There were no significant differences among distribution uniformities in the three fertilizer application treatments $(\mathrm{FH}, \mathrm{SH}, \mathrm{T})$. They observed that the injection particularly in the first half and during the entire irrigation event was better in terms of distribution uniformity and infiltrated fertilizer. However, best case observed in blocked-end conditions was injection in the second half of the irrigation event, preferably starting before completion of the advanced phase. Fertilizer losses due to runoff from the outlet were zero and distribution uniformity was somewhat higher, whereas in free-drainage conditions, fertilizer application during the first half of the irrigation provided acceptable fertilizer uniformity and lower fertilizer losses due to runoff. No significant difference was observed between the distribution uniformity of free-drainage and blocked-end experiments. A fertigation model was applied to the experimental data and the results showed good agreement with the field data. Fertilizer losses due to deep percolation in fertigation were not a concern when proper irrigation parameters were selected, such as inflow rate.

Many researchers have addressed the uniformity of surface fertigation by conducting field experiments on borders and furrows Playan and Faci, (1997); Garcia-Navarro et al., (2000); Abbasi et al., (2003c); Zerihun et al., (2003); Adamsen et al., (2005); Burguete et al., (2009), among others. Playan and Faci (1997) and Garcia-Navarro et al. (2000) found that application of fertilizers in short pulses did not result in high fertigation uniformity. The effect of injection time on bromide uniformity in borders and furrows showed that injection during the entire and second half of irrigation produced higher solute distribution uniformity Abbasi et al., (2003c); Adamsen et al., (2005); Burguete et al., (2009). Zerihun et al. (2003) found that nitrate distribution was a function of soil texture, soil hydraulic parameters, solute transport parameters, irrigation parameters and fertilizer management. They showed that improved irrigation management was needed in order to achieve acceptable distribution and uniformity in surface fertigation. These findings indicate that further studies on surface fertigation are needed to evaluate fertilizer runoff and deep percolation losses in different soils Boldt et al. (1994) presented a numerical model for simulating surface fertigation management in surge irrigation of furrows. The authors applied the model to hypothetical conditions for various soils, infiltration and furrow inflow rates, in order to develop optimum fertigation management strategies. Jaynes et al. (1992) conducted a fertigation experiment and compared the leaching behaviour of two conservative mobile tracers.

They studied the fate of bromide applied in the irrigation water and o-trifluoromethyl benzoic acid sprayed on the soil surface before irrigation. Results implied that fertilizers in irrigation water applied in level basins could potentially increase deep leaching of agricultural chemicals. Earlier studies have also indicated a rapid leaching along preferential flow paths when chemicals were applied with the irrigation water (Bowman and Rice, 1986; Jaynes et al., 1992). Preferential flow was also observed when tracers were applied to the soil by conventional methods before irrigation events (Rice et al., 1986). Under certain conditions, nitrate leaching could be reduced by $20-30 \%$ by separating water and fertilizer application Benjamin et al., (1998); Varlev et al., (1998); Popova et al., (2000). Benjamin et al. (1998), they studied the impact of fertilizer placement for alternate- and every-furrow irrigation systems over two irrigation seasons. They conclude that placing fertilizer in the non-irrigated furrow of an alternate furrow irrigation system, or placing fertilizer in the row, with either alternate or everyfurrow irrigation, decreased fertilizer leaching without reducing crop production. The problem with fertigation practices for furrow irrigation is that the mixture is not always uniformly distributed, and water draining off the field can carry fertilizer with it. Therefore, improper fertigation strategies might lead to loss of nitrogen fertilizer resulting in surface and groundwater pollution.

Evaluation and a numerical fertigation model was applied to simulate the measured experiments. Experiments were conducted in three soil textures and fertilizer was injected during the first half of the irrigation event $(\mathrm{FH})$, in the second half $(\mathrm{SH})$, and during the entire irrigation event $(\mathrm{T})$. These management strategies were conducted under free-draining and blocked-end conditions with a cutback method. Results indicated no significant differences between the distribution uniformities of blockedend and free drainage irrigation regimes. No significant differences were found among the distribution 
uniformities in the three fertilizer application timings (FH, SH, T). As fertilizer distribution uniformities behaved more or less the same during the different injection times, the application of fertilizer during the first half of the irrigation event was preferred to reduce fertilizer losses through runoff. Water and fertilizer losses due to deep percolation in fertigation would not be a major concern in case of selecting proper irrigation parameters. A fertigation model was applied to the experimental data and the results showed good agreement with field data. The fertigation model can be used as a suitable tool for optimizing fertilizer management in furrow-irrigated fields. Further studies should be conducted to evaluate the efficiency of surface fertigation with growing crops.

Nascimento, (2019) stated that non-uniform distribution and low irrigation efficiency might have effects on crop yield, crop water requirement Ascough, and Kiker, (2002). Crop water use efficiency Irmak et al. (2011) deep drainage Smith, et al. (2005), nitrate leaching, and soil nitrate content AllaireLeung et al. (2001) Along with irrigation efficiency, fertilizer uniformity is an evaluation criterion for irrigation and fertilizer application performance. Allaire-Leung et al. (2001), they study effect of sprinkler irrigation uniformity on leaching of nitrate and its content in a carrot crop. They noticed that non-uniformity of sprinkler has little impact on nitrate movement. For surface irrigation (furrow irrigation), low efficiency of irrigation may be due to poor design or irrigation control though irrigation efficiency can be increased with management strategies Valipour, (2013). Mohammadi et al. (2019) reported that applied optimal irrigation, application efficiency in the treatment of a row plant on a ridge of $37.5 \mathrm{~cm}$ (S0) increases by up to $9 \%$ and two rows plant on a ridge of $75 \mathrm{~cm}$ treatment (SR2) gradually increases up to $15 \%$ higher than the conventional irrigation. The distribution uniformity of Soil water and nitrate in furrow systems is generally required improving both irrigation and fertilizer management particularly in crop production in order to decrease environmental pollutions as well as maximization the fertilizers application. Using CV variation, heterogeneity along the length of border or furrow is weak for soil water content, moderate for both soil nitrate content, particularly, at the soil depth of 0 $20 \mathrm{~cm}$, and weak at the other soil layers for electrical conductivity.

Yuchun Liu, et al. (2020), reported that spatial and temporal distribution of soil water in the top $0-60 \mathrm{~cm}$ was more variable than that at a depth of $60-100 \mathrm{~cm}$. There was a significant correlation between the spatial and temporal distribution of electrical conductivity and nitrate. The soil nitrate content gradually decreased through the growth period and in deeper soil. There was a significant effect of fertilizer rate on the spatial distribution of EC and nitrate in the soil layer, and there was a decreasing trend in the soil EC and nitrate with decreasing in fertilizer rates. Irrigation types had a significant effect on the storage efficiency of water EW, the EW for border irrigation was $56.63 \%$, and was $1.1 \%$ lower than that for furrow irrigation over the whole growth period. The nitrate storage efficiency was $65.47 \%$ with no significant effect of irrigation type or fertilizer rate on nitrate storage efficiency. The uniformity of water and nitrate along the length of a border or furrow is weak to medium longer than $90 \mathrm{~cm}$, which can create non-uniform conditions for crop growth. The spatial and temporal distribution analysis indicates that furrow irrigation may store slightly more water in the top $0-60 \mathrm{~cm}$ of soil compared to border irrigation, and may more beneficial.

Nitrates in the soil are rapidly solubilized and moves with water, causing $\mathrm{N}$ losses due to the low adsorption capacity of soil to NO3 -N (Asadi et al., 2002; Di and Cameron, 2002). The results of some field experiments have suggested that $\mathrm{NO} 3-\mathrm{-N}$ leaching responds non-linearly to increasing $\mathrm{N}$ inputs. NO3 --N leaching is mainly affected by irrigation measures, nitrogen fertilizer management, crop system, soil management and soil type (Mlchabela et al., 2008; Rajput, and Patcl, 2006) Irrigated agriculture has been identified as a significant source of $\mathrm{NO}_{3}-\mathrm{N}$ pollution. Changes in irrigation systems mainly affect the mineralization and leaching of nitrogen by changing the soil water movement and affecting the distribution of available nitrogen in soil [9]. Furrow irrigation is currently the most common system used in many agricultural production areas around the world (Ayars, et al., 2017). However, drought events have forced farmers to restrict agricultural irrigation in this region Adopció et al. (2007) and some farmers are considering changing from furrow irrigation to a water saving irrigation system, such as sprinkler irrigation, which is generally considered a way to use water more efficiently (Souza and Folegatti, 2009). Sprinkler fertigation is the integration of water and fertilizer, which is one of the most widely used water saving and fertilizer saving irrigation methods (Sun et al., 2010). The wetting front in the soil profile is shallow under sprinkler fertigation, compared with furrow irrigation. The leaching of NO3 --N caused by different water distributions and its impact on the environment are different from sprinkler fertigation and furrow irrigation. At present, research on soil 
nitrogen distribution under sprinkler fertigation mainly focuses on the state of the art of the fixed sprinkler fertigation in wheat and corn fields (Sun, et al., 2010; Pang, et al., 1997).However, the study of $\mathrm{NO}_{3}-\mathrm{N}$ distribution, nitrogen balance and apparent nitrogen loss under sprinkler fertigation with low energy precision application (LEPA) sprinklers and furrow irrigation in potato fields is a lack of data support in arid and semi-arid areas. It is of great significance for the sustainable development of agriculture and the environment to optimize the irrigation and nitrogen management scheme of potato fields and provide technical guidance for the exploration of a standardized production mode suitable for high potato yield.

Irrigated cropland produces a large share of the total crop value in the United States, Furrow irrigation is used on about one-quarter or 5 million ha (USDA, 1998). Although furrow irrigation provides several important advantages over other irrigation methods, an important consequence is that surface runoff, which is commonly tolerated to improve water application uniformity along the furrows, is permitted to leave the field (Lehrsch et al., 2005). Th e water discharged from surface-irrigated fields can enter natural surface waters via return flow, is a potential source of contamination, and diffuse (nonpoint source) pollution. In the United States, the water quality of return flows was recognized as a management concern early in 1970 Bondurant, (1971); Law and Skogerboe, (1972), but more recently it has come to the fore in other surface-irrigated regions of the world (McHugh et al., 2008; Monaghan et al., 2009). The water quality issue related to agricultural irrigation and drainage remains one of the most difficult challenges facing agricultural and engineering professionals (Tanji and Keyes, 2002). Irrigation runoff from cropped fields can transport beneficial materials applied onsite to offsite environments where they may generate negative ecological consequences. These materials include sediment, organic carbon, salts, nutrients such as nitrate nitrogen $\left(\mathrm{NO}_{3}-\mathrm{N}\right)$, ammonium nitrogen $\left(\mathrm{NH}_{4}-\right.$ $\mathrm{N})$, potassium $(\mathrm{K})$, and phosphorus $(\mathrm{P})$, trace elements, pesticides, and microorganisms (Bondurant, 1971; Turner et al., 1980; Bjorneberg et al., 2002; Tanji and Keyes, 2002; Causapé et al., 2004). Sediment concentrations in runoff from recently tilled furrow irrigated fields commonly are 1000 to $10,000 \mathrm{mg} \mathrm{L}^{-1}$ Berg and Carter, (1980). The transported sediment and associated organic matter are an important source of N and P Heathwaite and Johnes, (1996), which play a dominant role in the eutrophication of both freshwater and ocean ecosystems (Correll, 1998). Bjorneberg et al. (2006) reported that runoff from furrow-irrigated fields contained mean dissolved reactive $P$ (DRP) concentrations ranging from 0.04 to $0.10 \mathrm{mg} \mathrm{L}^{-1}$ and total $\mathrm{P}(\mathrm{TP})$ ranging from 0.3 to $12.5 \mathrm{mg} \mathrm{L}^{-1}$, with the latter being linearly related to runoff suspended sediment. Runoff from a flood-irrigated hay meadow contained median reactive $\mathrm{P}$ concentrations of 0.53 to $18.12 \mathrm{mg} \mathrm{L}^{-1}$ and $\mathrm{NH}_{4}-\mathrm{N}$ concentrations of 0.11 to $3.46 \mathrm{mg} \mathrm{L}-1$, depending on the timing of a broadcast mono-ammonium phosphate fertilizer application (White et al., 2003). Reactive $\mathrm{P}$ in runoff from these flood-irrigated fields was greater than for furrow, because in the former, irrigation water flows over the entire field area (and hence exposure to broadcast $\mathrm{P}$ fertilizer is maximized), whereas in furrow only a fraction of the soil surface is contacted by water. Ultimately, 1.1 to $18 \%$ of applied reactive $\mathrm{P}$ and 0.1 to $3.3 \%$ of applied ammonium $\mathrm{N}$ was lost from the fertilized experimental plots in irrigation runoff, with greater amounts lost on more recently fertilized plots (White et al., 2003). Flood-irrigated pastures fertilized with superphosphate produced the greatest $\mathrm{P}$ losses in the first irrigation (Austin et al., 1996), and runoff losses decreased with time between fertilizer application and the first irrigation (Bush and Austin, 2001). Cessna et al. (2001), reported that nutrient concentrations in major surface drainage ditches of a Saskatchewan surface irrigation district averaged (a) $0.03-0.93 \mathrm{mg} \mathrm{L}^{-1}$ for TP. When the irrigation source water included only $0.017 \mathrm{mg} \mathrm{L}^{-1}$; (b) $0.007-0.035 \mathrm{mg} \mathrm{L}^{-1}$ reactive $\mathrm{P}$ relative to $0.003 \mathrm{mg} \mathrm{L}^{-1}$ in source water; and (c) $0.012-0.044 \mathrm{mg} \mathrm{L}^{-1}$ nitrate $\mathrm{N}$ compared with $0.031 \mathrm{mg} \mathrm{L}^{-1}$ present in source water. They concluded that $2.2 \%$ of TP and $1.9 \%$ of inorganic $\mathrm{N}\left(\mathrm{NH}_{4}-\mathrm{NO}_{3}-\mathrm{N}\right)$ applied, as fertilizer was lost in irrigation runoff. Little research has evaluated the effect of manure amendments on nutrient losses in runoff from surface-irrigated crops, although manure effects on nutrients in runoff resulting from actual or simulated rainfall events are well documented (Cabrera et al., 2009; Kleinman et al., 2002; Little et al., 2005; Smith et al., 2007; Gilley et al., 2007). Mundy et al. (2003) evaluated the effect of defoliation and cow stocking density on $\mathrm{P}$ and $\mathrm{N}$ in runoff from a flood-irrigated perennial pasture. One day after defoliation (cutting or grazing), flow-weighted filterable P and TP concentrations in runoff were 1.7 and $2.1 \mathrm{mg} \mathrm{L}^{-1}$, respectively, for a $375 \mathrm{cows} \mathrm{ha}^{-1}$ stocking-rate (short-term) treatment, while those for the lowest stocking-rate treatment ( 0 cows) were 1.5 and $1.5 \mathrm{mg} \mathrm{L}^{-1}$ (Mundy et al., (2003). No treatment differences in runoff $\mathrm{P}$ were observed by eight $\mathrm{d}$. after defoliation grazing (Westermann et al., 2001) 
measured $\mathrm{P}$ in runoff from furrow-irrigated plots having varying fertilizer and manure treatments; however, their data was limited in that (a) they monitored only a single irrigation in each of $2 \mathrm{yr}$.; (b) furrow length, inflow rates, and irrigation periods used were not typical for irrigation in the area; (c) manure treatments were applied to plots at least 4 yr. before their study; and (d) they did not represent fields with growing crops. Neither Bjorneberg et al. (2006) nor Westermann et al. (2001) monitored inorganic $\mathrm{N}$ or $\mathrm{K}$ in furrow streams. During furrow irrigation, the applied water streams interact with a fraction of the soil surface that would be exposed to a rainfall or flood-irrigation event.

Lentz and Lehrsch (2015) reported that addition of inorganic fertilizer or manure to soils could double or triple nutrient losses from furrow-irrigated fields. This increased nutrient loss from these cropped fields is a substantial and direct financial cost to the farmer and increases the potential for offsite ecological damage. This research points toward a need to develop management practices that can reduce nutrient losses from amended, furrow-irrigated soils. Nutrient runoff losses from control and treated soil suggests that the magnitude of annual nutrient losses in irrigation runoff depends not only on the type and amount of nutrient added to the soil but also on the timing of the application and attendant environmental factors. Results suggest that when amendments were incorporated into soil, runoff losses of soil dissolved reactive $\mathrm{P}$ (DRP) and inorganic $\mathrm{N}$ were substantially influenced by bio cycling processes. These processes determine the amounts and forms of nutrients that can be transported in furrow streams at any given time. Further study over more extended periods may be needed to better understand environmental effects on nutrient runoff potential.

\section{Advantages and disadvantages of furrow irrigation}

Furrow irrigation is irrigation where farmers flow water down small trenches running between their crops. Furrow irrigation works well for row crops, tree crops, because water does not directly contact the plants, crops that would be damaged by direct inundation by water such as tomatoes, vegetables, potatoes and beans.

\subsection{Advantages to furrow irrigation}

- Suitable for crops that are subjected to injury if water covers crown or stem

- With runoff return systems, furrows can be a uniform and efficient method.

- Provide better on-farm water management capabilities.

- Provide operational flexibility to achieve high efficiency

- A smaller wetted area can reduce evaporative losses on widely spaced crops.

- Low capital cost

- Less wastage of land on field ditches

- Provides good field drainage

- No crust formation

- Allows irrigation on sloping land

- No partial submergence

- Wets half to one third of land surface

\subsection{Disadvantages of furrow irrigation}

There are several disadvantages with furrow irrigation. These may include:

- High labour requirements (greater than other surface methods)

- Experience needed to divert water to furrows

- Mismanagement can severely degrade system performance

- Potential salinity hazards between furrows

- Greater possibility of tail water runoff (when end dikes are not used)

- Limited machine movement across field.

- Need one extra tillage practices (furrow making)

- Increased erosion potential

- More difficult to automate

- Poor lateral water spreading in sandy soils

- Land leveling needed for uniform furrow slope

- An accumulation of salinity between furrows; 
- An increased level of tail water losses; and the solution is to build retention ponds along the edges of fields that help capture this runoff, allowing it to be pumped back to the upslope side of the field for use in further irrigation cycles.

- The difficulty of moving farm equipment across the furrows;

- The added expense and time to make extra tillage practice (Furrow Construction);

- An increase in the erosive potential of the flow;

- Needing to level and remove any small hills that would have been bypassed by the gravity flow of the water because difficulties of furrow irrigation are ensuring uniform dispersion of water over a given field.

- Generally furrow systems are more difficult to automate, particularly with regard to regulating an equal discharge in each furrow

- That is all of furrow irrigation advantages and disadvantages that are the oldest methods of irrigation.

\section{Conclusions}

In almost all regions of the world, water supply is the main constraint to crop production due to water demand for rapid industrialization and high population growth. Water is increasingly recognized as a major component in economic development and poverty reduction. Agriculture is the largest freshwater user on the planet, consuming more than two thirds of total with drawals. Surface irrigation is the most common executed irrigation due to its low capital cost, no special technical experience regarding operation and maintenance and no specific equipment are required because of long practical background among local farmers regarding the implementation of this irrigation system. Furrow irrigation is most widely used among the surface irrigation methods. In this system, water is applied by means of small channels or furrows, which follow a uniform longitudinal slope. Furrow irrigation has low application efficiency because of its high water loss due to surface runoff, evaporation from water in the furrow, evaporation from the soil surface and percolation below root zone. Alternate furrow irrigation is a system of irrigating only one side of the plant, i.e., half of the root system, is irrigated at first irrigation event, while the other side receives water on the next irrigation.

Surface irrigation would be the main irrigation methods for a long time in several countries particularly. However, the traditional surface irrigation cannot adapt to the needs of the development of modern agricultural technology, because it has disadvantages such as lower irrigation uniformity, high irrigation water consumption and, carrying out efficient water-saving surface irrigation technology in future is the main development direction of agricultural irrigation. To improve surface irrigation technology and vigorously carry out the precision surface irrigation technology as the representative of the modern surface irrigation technology, and actively promote water-saving border irrigation, furrow irrigation, surge irrigation and other advanced surface irrigation technology, vigorously carry out laser leveling technology and real time feedback control technology to improve surface irrigation field irrigation management level. Furrow irrigation can cause excessive soil losses, which lead to the degradation of the soil in the upper part of the field and pollution of the surface water receiving the tail water. For whole-furrow length and irrigation event, the soil loss tolerance was exceeded in the inflow particularly in slope However; the soil loss in the head-end portion of the furrows was always greater than the soil loss tolerance, indicating that periodical within-field soil redistribution is required to maintain the quality of the soil. However, managing the irrigation in such a way for achieve high irrigation uniformity and application efficiency, while keeping soil losses below a sustainable limit. Laser leveling technology is the most advanced land leveling technology in the world, it has been widely used in developed countries at present, and our country is still in the stage of introduction, demonstration and popularization. Based on laser control technology, global positioning system (GPS) and geographic information system (GIS), realize the achievement of laser control land precision leveling technology, effectively improve the micro topography of the field and effectively use of irrigation water, and can achieve precision surface irrigation. Additional experimental together with the development of simulation models, should assist in future to rationally establish the maximum non-erosive furrow inflow in relation to other irrigation variables. Field irrigation quality and irrigation efficiency; enhance the level of modern agricultural development in different part of the world.

Our recommendation can be drawn as follows

- Furrow bed irrigation is one of the efficient surface irrigation methods but needs appropriate Land, water and irrigation management for harvesting the full potential 
Productivity and water saving benefits;

- The furrow bed design should be site specific depending on soil type, slope, field length, water source, inflow rate, crop type and available machinery;

- Initial field investigation should be conducted for determining soil physical and hydro chemical characteristics. The land leveling and input requirements should be fulfilled as per site specific needs before and after installation of furrow beds;

- The soil management should involve minimum soil disturbance by avoid in intensive tillage and compaction while enhancing crop residue retention and soil cover or mulching;

- The irrigation management should reduce advance time to field tail end and tail water

Collection and to ensure lateral infiltration to meet water needs of crop in bed middle:

- Additional measures of constructing farm pond, insect, pest and weeds management needs to be undertaken. The furrow spacing should match the tractor track width and crop rotation should be followed.

\section{References}

Abbasi, F., J. Simunek, M.T. van Genuchten, J. Feyen, F.J. Adamsen, D.J. Hunsaker, T.S. Strelkoff, and P. Shouse, 2003c. Overland water flow and solute transport: model development and field data analysis. Journal of Irrigation and Drainage Engineering, 129 (2):71-81.

Abebe, C., W.G. Gebremedhin, M. Daniel and A. Amsalu, 2016. Review of Potato Agronomic Research in Central highlands of Ethiopia: Achievements and Future Prospects. International journal of advances in life science and technology, 51:8-14.

ABS. 2010, Water use in Australian Farms, 2008-09, Australian Bureau of Statistics.

Adamsen, F.J., D.J. Hunsaker, and H. Perea 2005. Border strip fertigation: effect of injection strategies on the distribution of bromide. Transactions of ASAE, 48(2): 529-540.

Adisu, T.E., and S. Teshome, 2018. The Impact of Alternate Furrow Irrigation on Water Productivity and Yield of Potato at Small Scale Irrigation,Ejere District, West Shoa, Ethiopia.Applied Engineering, 2(1): 1-18, doi: 10.11648/j.ae.20180201.11

Adopció de Measures Excepcionals i D’emergència en Relació Amb la Utilització Dels Recursos Hídrics, 2nd ed., Diari Oficial de la Generalitat de Catalunya: Barcelona, Spain, 2007; 84-86.

Alexandratos, N. and J. Bruinsma, 2012. World agriculture towards 2030/2050: the 2012 revision, Tech. Rep. 12, FAO, Rome, FAO,

Allaire-Leung, S., L. Wu, J. Mitchell, and B. Sanden, 2001. Nitrate leaching and soil nitrate content as affected by irrigation uniformity in a carrot field. Agricultural Water Management, 48: 37-50.

Allen, N.L., 1980. Advance Rates in Furrow Irrigation for Cycled Flow. M.S. thesis, Utah State University, Logan, Utah

Asadi, M.E., R.S. Clemente, A.D. Gupta, R. Loof, and G.K. Hansen, 2002. Impacts of fertigation via sprinkler irrigation on nitrate leaching and corn yield in an acid-sulphate soil in Thailand. Agric. Water Manag. 52: 197-213. [CrossRef]

Ascough, G. and G.T. Kiker, 2002. Effect of irrigation uniformity on irrigation water requirements. Water Sa, 28: 235-242 .

Ascough, G.W. and G.A. Kiker, 2004. The effect of irrigation uniformity on irrigation water requirements, ISSN 0378-4738 = Water SA.,28 (2).

Austin, N.R., J.B. Prendergast, and M.D. Collins. 1996. Phosphorus losses in irrigation runoff from fertilized pasture. J. Environ. Qual., 25:63-68.

Ayars, J.E., C.J. Phene, R.C. Phene, S.D. Gao, D. Wang, K.R. Day, and D.J. Makus, 2017. Determining pomegranate water and nitrogen requirements with drip irrigation. Agric. Water Manag., 187: 11-23. [CrossRef]

Ayers, R.S., and D.W. Westcote, 1994.Water quality for agriculture. FAO Irrigation and Drainage Paper 29. Rome.

Bautista, E., L. Hardy and M. English, 2009. Estimation of soil and crop hydraulic properties for surface irrigation: theory and practice. ASAE Annual Meeting. California, USA, pp1-13.

Benjamin, J.G., L.K. Porter, H.R. Duke, L.R. Ahuja, and G. Butters, 1998. Nitrogen movement with furrow irrigation method and fertilizer band placement. Soil Science Society of America Journal, 62:1103-1108. 
Berg, R.D., and D.L. Carter. 1980. Furrow erosion and sediment losses on irrigated cropland. J. Soil Water Conserv. 35:267-270.

Bjorneberg, D.L., D.T. Westermann, and J.K. Aase, 2002. Nutrient losses in surface irrigation runoff. J. Soil Water Conserv., 57:524-529.

Bjorneberg, D.L., D.T. Westermann, J.K. Aase, A.J. Clemmens, and T. Strelkoff, 2006. Sediment and phosphorus transport in irrigation furrows. J. Environ. Qual. 35:786-794.

Boldt, A.L., D.G. Watts, D.E. Eisenhauer, J.S. Schepers, 1994. Simulation of water applied nitrogen distribution under surge irrigation. Transactions of ASAE., 37(4): 1157-1165.

Bondurant, J.A., 1971. Quality of surface irrigation runoff water. Trans. ASAE14:1001-1003.

Bowman, R.S., and R.C. Rice, 1986. Transport of conservative tracers in the field under intermittent flood irrigation. Water Resources Research, 22: 1531-1536

Burguete, J., N. Zapata, P. García-Navarro, M. Maïkaka, E. Playán, and J. Murillo, 2009. Fertigation in furrows and level furrow systems. Field experiments, model calibration, and practical applications. Journal of Irrigation and Drainage Engineering, 135(4): 413-420

Bush, B.J., and N.R. Austin, 2001. Timing of phosphorus fertilizer application within an irrigation cycle for perennial pasture. J. Environ. Qual., 30:939-946.

Cabrera, V.E., L.J. Stavast, T.T. Baker, M.K. Wood, D.S. Cram, R.P. Flynn, and A.L. Ulery, 2009. Soil and runoff response to dairy manure application on New Mexico rangeland. Agric. Ecosyst. Environ., 131:255-262.

Causapé, J., D. Quilez, and R. Aragüés, 2004. Salt and nitrate concentrations in the surface waters of the CR-V irrigation district (Bardenas I, Spain): Diagnosis and prescriptions for reducing off site contamination. J. Hydrol., 295:87-100.

Cessna, A.J., J.A. Elliott, L. Tollefson, and W. Nicholaichuk, 2001. Herbicide and nutrient transport from an irrigation district into the South Saskatchewan River. J. Environ. Qual., 30:1796-1807.

Correll, D.L., 1998. The role of phosphorus in the eutrophication of receiving waters: A review. J. Environ. Qual., 27:261-266.

Di, H.J., and K.C. Cameron, 2002. Nitrate leaching in temperate agroecosysterns: Sources, factors and mitigating strategies. Nutr. Cycl. Agroecosyst., 46: 237-256. [CrossRef]

Evans, R.G., J.A. Aarsted, D.E. Miner, and M.W. Kroeger, 1985. Crop Residue Effects on Furrow Irrigation Advance and Infiltration. Pap. 85-2586. ASAE Winter Meeting, Chicago, Ill.

FAO (Food and Agricultural Organization), 2012. Crop yield response to water: FAO irrigation and drainage paper 66. Food and Agricultural organization, Rome, Italy.

FAO (Food and Agricultural Organization), 2019. Field guide to improve water use efficiency in small - scale agriculture, the case of Burkina Faso, Morocco, and Uganda FAO irrigation and Food and Agricultural organization, Rome, Italy.

Fariborz, A., T.R. Heidar, J. Mohammad and A.A. Hamzeh, 2012. valuation of fertigation in different soils and furrow irrigation regimes, Irrig. and Drain., 61: 533-541.

Fernández-Gómez, R., L. Mateos, and J.V. Giráldez, 2004. Furrow irrigation erosion and management, Irrig Sci 23: 123-131. DOI 10.1007/s00271-004-0100-3

Food and Agriculture organization of THE United Nation Cairo, (FAO), 2017. Does improved irrigation technology save water? A Review of the evidence

Francoise, L.E., and E.V. Maas, 1978. Plant responses to salinity: An indexed bibliography. USDA, ARM-W-6, 291.

Francoise, L.E., and E.V. Maas, 1985. Plant responses to salinity: A supplement to an indexed bibliography. USDA, ARS-24, 174 .

Gao, X., W. Yechou and H. Jianfeng, 2012. Application on effects of laser control of flatting ground and water saving technology in several crop planting modes in Jiuquan city. Water Saving Irrigation, (11): 61-63.

Garcia-Navarro, P., E. Playan, and N. Zapata, 2000. Solute transport modeling in overland flow applied to fertigation. Journal of Irrigation and Drainage Engineering, 126(1): 33-40.

Gharbi, A., 1984. Effect of flow fluctuations on free-draining and sloping furrow and border irrigation systems. MS Thesis, Agricultural and Irrigation Engineering. Utah State University, Logan, Utah. Unpublished document. 123.

Gilley, J.E., B. Eghball, and D.B. Marx. 2007. Nutrient concentrations of runoff during the year following manure application. Trans. ASABE 50:1987-1999. 
Hart, W.E., H.J. Collins, G. Woodward, and A.J. Humpherys, 1980. Design and operation of gravity on surface systems, Chapter 13, In: Design and Operation of Farm Irrigation Systems. ASAE Monograph Number 3, St. Joseph, Michigan. 829.

Heathwaite, A.L., and P.J. Johnes, 1996. Contribution of nitrogen species and phosphorus fractions to stream water quality in agricultural catchments. Hydrol. Processes 10:971-983.

Irmak, S., L.O. Odhiambo, W.L. Kranz, and D.E. Eisenhauer, 2011. Irrigation efficiency and uniformity, and crop water use efficiency.

Ismail, S.M. and G.L. Westesen, 1984. Surge flow border irrigation using an automatic gate. Paper 842069 presented at the Winter Meeting of ASAE, Chicago, Illinois.

Jägermeyr J, D. Gerten, J. Heinke, S. Schaphoff, M. Kummu, and W. Lucht, 2015. Water savings potentials of irrigation systems: global simulation of processes and linkages, Hydrol. Earth Syst. Sci., 19: 3073-3091.

Jat, M.L., P. Chandna, R.K. Gupta, S.K. Sharma, and M.A. Gill, 2006. Laser Land Leveling: A Precursor Technology for Resource Conservation. Rice-Wheat Consortium Technical Bulletin Series 7, Rice-Wheat Consortium for the Indo-Gangetic Plains, New Delhi, India.

Jat, M.L., M.K. Gathala, J.K. Ladha, Y.S. Saharawat, A.S. Jat, V. Kumar, S.K. Sharma, V. Kumar, and R. Gupta, 2009a. Evaluation of precision land leveling and double zero-till systems in the ricewheat rotation: Water use, productivity, profitability and soil physical properties. Soil Till Res. 105: 112-121.

Jat, M.L., R. Gupta, P. Ramasundaram, M. Gathala, H.S. Sidhu, S. Singh, R.G. Singh, Y. Saharawat, V. Kumar, and P. Chandna, 2009b. Laser-assisted precision land leveling: A potential technology for resource conservation in irrigated intensive production systems of the Indo-Gangetic plains. In: Ladha JK, Yadvinder-Singh, Erenstein O, Hardy B (eds). Integrated Crop and Resource Management in the Rice-Wheat System in South Asia. International Rice Research Institute, Los Banos, Philippines, 223-238.

Jat, M.L., R. Gupta, Y.S. Saharawat, R. Khosla, 2011. Layering precision land leveling and furrow irrigated raised bed planting: Productivity and input use efficiency of irrigated bread wheat in Indo-Gangetic plains. Am J Plant Sci., 2: 578-588.

Jat, M.L., S.S. Pal, A.V.M. Subba Rao, K. Sirohi, S.K. Sharma, and RK. Gupta, 2004. Laser land leveling: The precursor technology for resource conservation in irrigated eco-system of India. Proceedings of the National Conference on Conservation Agriculture, New Delhi, India, 9-10.

Jat, M.L., 2012. Laser land leveling in India: A success. Presentation given at the conference "Lessons Learned from Postharvest and Mechanization Projects, and Ways Forward." Asian Development Bank's Postharvest Projects' Post-production Workgroup of the Irrigated Rice Research Consortium (IRRC), held at the International Rice Research Institute, Los Banos, Manila, Philippines, May, 22-24.

Jat, M.L., S. Yadvinder, G. Gerard, H.S. Sidhu, P.A. Jeetendra, S. Clare, and G. Bruno (2015). LaserAssisted Precision Land Leveling Impacts in Irrigated Intensive Production Systems of South Asia, Soil-Specific Farming.

Jaynes, D.B., R.C. Rice, and D.J. Hunsaker, 1992. Solute transport during chemigation of a level basin. Transactions of ASAE., 35(6): 1809-1815

Khepar, S.D., M.C. Chaturvedi, and B.K. Sinha, 1982. Effect of precise leveling on the increase of crop yield and related economic decision. J Agric Engg., 19: 23-30.

Kleinman, P.J.A., A.N. Sharpley, B.G. Moyer, and G.F. Elwinger. 2002. Effect of mineral and manure phosphorus sources on runoff phosphorus. J. Environ. Qual., 31:2026-2033.

Kukal, S.S., G.S. Hira, and A.S. Sidhu, 2005. Soil matric potential-based irrigation scheduling to rice (Oryza sativa). Irrig Sci., 23: 153-159.

Kunlun, D., 2019. State of knowledge of irrigation techniques and practicalities within given socioeconomic settings. Irrig. and Drain., 68: 31-45

Lanie, A.A., and N.E.Jr Armando, 2020. Evaluation of the SIRMOD model for optimum furrow irrigation performance Agric Eng Int: CIGR Journal, 22(1).

Law, J.P., Jr., and G.V. Skogerboe, 1972. Potential for controlling quality of irrigation return flows. J. Environ. Qual., 1:140-145.

Lehrsch, G.A., D.L. Bjorneberg, and R.E. Sojka, 2005. Erosion: Irrigation induced. Vol. 1. p. 456-463. In D. Hillel (ed.) Encyclopedia of soils in the environment. Elsevier, Oxford, UK. 
Lentz R. D and G.A. Lehrsch, 2015. Nutrients in Runoff from a Furrow-Irrigated Field after Incorporating Inorganic Fertilizer or Manure, Journal of Environmental Quality ·

Little, J.L., D.R. Bennett, and J.J. Miller, 2005. Nutrient and sediment losses under simulated rainfall following manure incorporation by different methods. J. Environ. Qual. 34:1883-1895.

Maas, E.V., 1990. Crop salt tolerance. Chapter 13, In: Agricultural salinity assessment and management. ASCE Manual and Reports on Engineering Practice No. 71. American Society of Civil Engineers (Tanji KK Editor), 262- 304.

Marr, J.C.,1967. Grading land for surface irrigation. Circular 408, California Agricultural Experiment Station, University of California, Davis, California.

McHugh, A.D., S. Bhattarai, G. Lotz, and D.J. Midmore, 2008. Effects of subsurface drip irrigation rates and furrow irrigation for cotton grown on a vertisol on off -site movement of sediments, nutrients, and pesticides. Agron. Sustain. Dev. 28:507-519.

Mlchabela, M.S., A. Madam, R. Gordon, D. Burton, D. Cudmore, A. Elmi, and W. Hart, 2008. Gaseous and leaching nitrogen losses from no tillage and conventional tillage systems following surface application of cattle manure. Soil Tillage Res., 98: 187-199. [CrossRef]

Mohammadi, A., S. Besharat, and F. Abbasi, 2019. Effects of irrigation and fertilization management on reducing nitrogen losses and increasing corn yield under furrow irrigation. Agricultural Water Management, 213, 1116-1129, https://doi.org/10.1016/j. agwat.2018.11.007

Mohmed A.E., E.M. Abd Elmonem, and A.S. Salah, 2014. Effect of some techniques on long furrow irrigation efficiency International Conference on Biological, Civil and Environmental Engineering (BCEE-2014) March 17-18, Dubai (UAE).

Monaghan, R.M., P.L. Carey, R.J. Wilcock, J.J. Drewry, D.J. Houlbrooke, J.M. Quinn, and B.S. Th orrold. (2009). Linkages between land management activities and stream water quality in a border dyke-irrigated pastoral catchment. Agric. Ecosyst. Environ. 129:201-211.

Mundy, G.N., K.J. Nexhip, N.R. Austin, and M.D. Collins. 2003. Th e influence of cutting and grazing on phosphorus and nitrogen in irrigation runoff from perennial pasture. Aust. J. Soil Res., 41:675685 .

Nascimento, A., 2019. Efects of irrigation uniformity on yield response and production economics of maize in a semiarid zone. Agricultural Water Management, 211:178-189.

National Engineering Handbook, 2006. Surface Irrigation, Part 623 Irrigation, United States Department of Agriculture Natural Resources Conservation Service

Pang, X.P., J. Leley, and L. Wu, 1997. Irrigation quantity and uniformity and nitrogen application effects on crop yield and nitrogen leaching. Soil Sci. Soc. Am.J., 61: 257-261. [CrossRef]

Playan, E., and J.M. Faci, 1997. Border irrigation: field experiment and a simple model. Irrigation Science, 17(4): 163-171.

Plusquellec, H., 2009. Modernization of large-scale irrigation systems: is it an achievable objective or a lost cause?' Irrigation and Drainage, 58: 104-120.

Popova, Z., I. Varlev, V. Kutev, and D. Shopova, 2000. Lysimeter study on ground water degradation due to different fertilisation and irrigation management. Soil Science Agro-Chemistry, 35: 19-23

Qunchang, L., D. Xu and X. Chongbao, 2002. Soil and water engineering adaptability of surge flow irrigation applying on farmland. Transactions of the CSAE, 18 (1):35-40.

Raine, S.R., D.J. McClymont and R.J. Smith, 2001.The effect of variable infiltration on design and management guidelines for surface irrigation. NCEA, The University of Southern Queensland, Australia.

Rajput, T.B.S., and N. Patcl, 2006. Water and nitrate movement indrip-irrigated onion under fertigation and irrigation treatments. Agric. Water Manag., 79: 293-311. [CrossRef]

Rice, R.C., R.S. Bowman, D.B. Jaynes, 1986. Percolation of water below an irrigated field. Soil Science Society of America Journal, 50: 855-859.

Rudragouda, C., Y. Ravindra, P.S. Kanannavar, B.R. Vasantagouda, and M. Kumar, 2012. Precision leveling: Its impact on slope variation in vertisols of Karnataka. Proc Agro-Informatics Precision Agric, India, 332-334.

Shen, H., T. Juncang and W. Hongwei, 2007. Progress of laser control technique. Ningxia Engineering Technology, 6(2):121-132.

Shen, H., T. Juncang and L. Zhuo, 2006. Application and the effect of laser-controlled land leveling technology in Yellow River irrigation area. Water Saving Irrigation, (6):35-38. 
Sikka, P., 2008. Enterprise culture and accountancy firms: New masters of the universe, Accounting Auditing and Accountability Journal $\cdot$ February

Smith, D.R., P.R. Owens, A.B. Leytem, and E.A. Warnemuende, 2007. Nutrient losses from manure and fertilizer applications as impacted by time to first runoff event. Environ. Pollut., 147:131137.

Smith, R.J., S.R. Raine, and J. Minkovich, 2005. Irrigation application efficiency and deep drainage potential under surface irrigated cotton', Agricultural Water Management, 71(2): 117-130.

Souza, C.F., M.V. Folegatti, and D. Or, 2009. Distribution and storage characterization of soil solution for drip irrigation. Irrig. Sci., 27: 277-288. [CrossRef]

Sun, Z.Q., Y.H. Kang, and S.F. Jiang, 2010. Effect of sprinkler and border irrigation on topsoil structure in winter wheat field. Pedosphere 20: 419-426. [CrossRef]

TaiSheng, D., K. ShaoZhong and W. ZhenChang, 1990. Responses of cotton growth, yield, and WUE to alternate furrow irrigation. Acta Agronomica Sinica, 2007, 33 (12):1982.

Tanji, K.K., and C.G. Keyes. 2002. Water quality aspects of irrigation and drainage: Past history and future challenges for civil engineers. J. Irrig. Drain. Eng. 128:332-340.

Turner, F.T., K.W. Brown, and L.E. Deuel. 1980. Nutrients and associated ion concentrations in irrigation return $\mathrm{fl}$ ow from $\mathrm{fl}$ ooded rice fields. J. Environ. Qual., 9:256-260.

USDA., 1998. Farm and ranch irrigation survey. In 1997 census of agriculture. Vol. 3. Special Studies. USDA, National Agricultural Statistics Service, Washington, DC.

Valipour, M., 2013. Increasing irrigation efficiency by management strategies: cutback and surge irrigation. Journal of Agricultural and Biological Science, 8: 35-43.

Varlev, I., Z. Popova, B. Mladenova,1998. Alternative furrow irrigation under the conditions of cinnamonic forest red soils. Part I. Uniformity of water distribution and yield. In: Proceedings of the Research Institute for Irrigation, Drainage and Hydraulic Engineering (in Bulgarian); 142 148

Walker, W.R., 1989. Guidelines for designing and evaluating surface irrigation systems', FAO Irrigation Drainage Paper 45.

Walker, W.R., and T.S. Lee, 1981. Kinematic-Wave Approximations of Surged Furrow Advance. Pap 81-2544. ASAE Winter Meeting, Chicago, Ill., December, 15-18.

Walker, W.R. and G.V. Skogerboe, 1987. Surface Irrigation: Theory and Practice. Prentice-Hall, Englewood Cliffs, New Jersey. 386.

Wenzhu, Y., J. Yan, Y. Mingde, W. Huiyang, G. Peng, Y. Jie, L. Lijia and Y. Junxia, 2020. Minimizing Soil Nitrogen Leaching by Changing Furrow Irrigation into Sprinkler Fertigation in Potato Fields in the Northwestern China Plain, Water, 12: 2229.

Westermann, D.T., D.L. Bjorneberg, J.K. Aase, and C.W. Robbins. 2001. Phosphorus losses in furrow irrigation runoff . J. Environ. Qual., 30:1009-1015.

White, S.K., J.E. Brummer, W.C. Leininger, G.W. Frasier, R.M. Waskom, and T.A. Bauder. 2003. Irrigated mountain meadow fertilizer application timing eff ects on overland $\mathrm{fl}$ ow water quality. J. Environ. Qual., 32:1802-1808.

Xiulu, S., H. Xiuqiao and L. Jinshan, 2015. Field experimental study on soil water and nitrogen distributions under surge flow irrigation. Journal of Irrigation and Drainage, 34 (1): 33-38.

Yinghua, P. and K. Shaozhong, 2000. Irrigation water infiltration in furrows and crop water use of alternative furrow irrigation. Transactions of the CSAE, 16 (1):39-43.

Yuchun, L., W. Ning, J. Changsong, A. Leigh and W. Yao, 2020. Temporal and spatial distribution of soil water and nitrate content affected by surface irrigation and fertilizer rate in silage corn fields Scientific Reports, 10:8317

Yuliang, F., F. Liangjun and N. Weibo, 2016.Intermittent infiltration of surge irrigation model research based on Green-Ampt and Philip models. Transactions of the Chinese Society for Agricultural Machinery, 47 (9):194-201.

Zerihun, D., C.A. Sanchez, K.L. Farrell-Poe, F.J. Adamsen, D.J. Hunsaker, 2003. Performance indices for surface N fertigation. Journal of Irrigation and Drainage Engineering, 129(3): 173-183. 